\title{
The Rise of Corporate Governance in the U.K.: When and Why
}

\author{
Brian R. Cheffins*
}

(April 2015 draft)

\begin{abstract}
While issues that prompt corporate governance responses are endemic to the corporate form, the term "corporate governance" only began to feature with any regularity in discussions of public companies in Britain as the 1990s got underway. It is well known that work done by the Committee on the Financial Aspects of Corporate Governance, known as the Cadbury Committee, played a major role in fostering the rise of corporate governance in the U.K. at that point. This paper explains why corporate governance did not move into the spotlight in Britain in the 1970s, a development that might have been anticipated given that corporate governance was arriving on the scene in the United States then. The paper also identifies trends that likely would have ensured that corporate governance would have risen to prominence in Britain in the early 1990s in the absence of the Cadbury Committee's deliberations.
\end{abstract}

Keywords: corporate governance; boards of directors; takeovers; executive pay

JEL Codes: G34, G38, K22, N24

S.J. Berwin Professor of Corporate Law, Faculty of Law, University of Cambridge. This paper is based on a lecture delivered as part of the Current Legal Problems lecture series organized by the Law Faculty of University College London. I am grateful for feedback received at the lecture and from Ewan McCaughey. 


\section{Introduction}

This paper addresses in the British context the timing of and the causes underlying the rise of corporate governance, which encompasses the checks and balances affecting those who run companies. ${ }^{1}$ The topic of corporate governance is currently a core feature of the landscape in which publicly traded U.K. companies operate. One might correspondingly expect that the term "corporate governance" would always have been a feature of debates in Britain on such firms. Issues that prompt corporate governance responses are indeed endemic to the corporate form, ${ }^{2}$ particularly in a publicly traded company. So long as this sort of firm lacks a dominant shareholder - the typical situation in large British public companies for decades $^{3}$-- there is unlikely to be any one investor who has the wherewithal to keep management in line. Hence, if one assumes in the same fashion as the 2009 Walker Report on the corporate governance of banks that " $(\mathrm{t})$ he role of corporate governance is to protect and advance the interests of shareholders," in U.K. public companies managerial "agency costs" generated by inattentive or self-serving executives unconstrained by shareholders stand out as the major potential governance risk. ${ }^{5}$

1 Robert E. Wright, Corporation Nation (University of Pennsylvania Press 2014), 152.

2 Brian R. Cheffins, 'The History of Corporate Governance', in Mike Wright, Donald Siegel, Kevin Keasey and Igor Filatotchev (eds), The Oxford Handbook of Corporate Governance (OUP 2013), 46, 46. See also Klaus J. Hopt, 'New Ways in Corporate Governance: European Experiments with Labor Representation on Corporate Boards' (1984) 82 Mich L Rev 1338, 1338 ('Corporate governance has been discussed in Europe for over 150 years.')

3 Text to nn 33-34.

4 David Walker, A Review of Corporate Governance in UK Banks and Other Financial Industry Entities: Final Recommendations (Walker Review Secretariat, 2009), 23. On "shareholder/stakeholder" governance problems see Brian R. Cheffins, 'Introduction' in Brian R. Cheffins, ed., The History of Modern U.S. Corporate Governance (Edward Elgar, 2011), ix, $x$.

$5 \quad$ Brian Cheffins and Steven Bank, 'Is Berle and Means Really a Myth?' (2009) 83 Bus Hist Rev 443, 443-44. The pioneering work on managerial agency costs was Michael C. 
Concerns have been expressed in the U.K. since at least the late $18^{\text {th }}$ century that large business enterprises are afflicted by managerial accountability shortcomings and shareholder apathy. ${ }^{6}$ Nevertheless, in Britain the concept of corporate governance only explicitly became an integral feature of the public company landscape at the beginning of the 1990s. A 1992 report and Code of Best Practice issued by Sir Adrian Cadbury and the Committee on the Financial Aspects of Corporate Governance he chaired stand out as the most obvious explanation why "corporate governance" rose to prominence at that point in time. ${ }^{7}$

The history of the Cadbury Committee has been canvassed in detail. ${ }^{8}$ Nevertheless, more remains to be said about the rise of corporate governance in the U.K. This paper does so in two ways. First, it explains why corporate governance did not achieve prominence in the U.K. in the 1970s despite this occurring in the United States. Second, the paper argues that corporate governance would in all likelihood have become topical in Britain in the early 1990s in the absence of the Cadbury Committee, identifying in so doing trends that would have led to this outcome.

The chronology of corporate governance means that the U.S. experience features prominently in the account offered here of the rise of corporate governance in Britain. Part of the reason is that the U.S. was a "first mover." The term "corporate governance" was used initially with regularity in the U.S. in the 1970s; the terminology only came into general

Jensen and William H. Meckling, 'Theory of the Firm: Managerial Behavior, Agency Costs and Ownership Structure' (1976) 3 J Fin Econ 305.

6 Brian R. Cheffins, Corporate Ownership and Control: British Business Transformed (Oxford University Press, 2008), 2.

7 Committee on the Financial Aspects of Corporate Governance, Report, (Gee, 1992) Committee on the Financial Aspects of Corporate Governance, Code of Best Practice (Gee, 1992).

$8 \quad$ Laura F. Spira and Judy Slinn, The Cadbury Committee: A History (OUP, 2012). 
usage elsewhere a couple of decades later. ${ }^{9}$ Also important is that trends which in the U.S. sustained corporate governance in the 1980s as a topic for debate and set the scene for corporate governance to become entrenched as a key feature of the public company landscape in the 1990s were also present in the U.K. It is these trends that explain why even in the absence of Cadbury corporate governance likely was destined to become a prominent issue in Britain as the 1990s got underway.

The paper begins by describing the arrival of corporate governance in the 1970s in the United States. The scene then switches to Britain, with the focus being on explaining why corporate governance failed to catch on in this era in Britain in the same way it did in the U.S. Evidence will then be provided on how the concept of corporate governance initially achieved prominence in Britain as the 1990s got underway and the major contribution the Cadbury Committee made on this front will be acknowledged. Next, there will be discussion of trends concerning publicly traded companies and their executives that were present in both the U.S. and the U.K. as the $20^{\text {th }}$ century drew to a close that left Britain primed for corporate governance to move to the forefront even absent the work of the Cadbury Committee. Global developments occurring in the 1990s are taken into account briefly to conclude the paper.

The United States as a Corporate Governance "First Mover"10

The United States experienced during the opening decades of the $20^{\text {th }}$ century what distinguished business historian Alfred Chandler would characterize as a "managerial

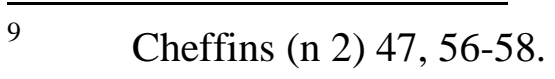

10 The sections of this paper that deal with the U.S. draw heavily on other research of mine. See Cheffins (n 2); Cheffins (n 4); Brian R. Cheffins, 'The Corporate Governance Movement, Banks and the Financial Crisis' (2015) 16 Theo Inquiries in Law 1. For full citations supporting the propositions advanced here concerning the U.S., please refer to these sources. 
revolution". ${ }^{11}$ A growing division between share ownership and managerial control and the development of increasingly sophisticated managerial hierarchies were hallmarks of this transition. By the 1950s and 1960s, "managerial capitalism had triumphed", ${ }^{12}$ with enterprises with full-time professional executives fully in charge dominating pivotal sectors of the U.S. economy.

When World War II ended, the U.S. experienced a prolonged economic boom, successful corporations grew rapidly and, as an incidental by-product, shares in public companies performed well. Moreover, scandals, while not unknown, were the exception to the rule as senior executives of U.S. public companies refrained for the most part from taking personal advantage of their position as stewards of corporate assets. Correspondingly, during the "heyday of...corporate managerialism"13 the internal governance of companies was not a high priority and the phrase "corporate governance" was rarely uttered.

Matters began to change in the 1970s. Sprawling corporate empires built or expanded in the 1950s and the 1960s proved difficult to run, a trend underscored by the 1970 collapse of Penn Central, a railway-based conglomerate. Corruption emerged shortly thereafter as a cause for concern amidst revelations that dozens of U.S. public corporations had engaged in bribery and related misconduct, both at home and abroad. The federal Securities Exchange Commission (SEC) responded to the Penn Central debacle and the illicit payment revelations by bringing corporate governance explicitly on to the official agenda. In addition to holding hearings in 1977 on corporate governance and shareholder democracy the SEC launched

11 Alfred D. Chandler, The Visible Hand: The Managerial Revolution in American Business (Belknap Press, 1977) 484.

12 Alfred D. Chandler, 'The United States: Seedbed of Managerial Capitalism' in Alfred D. Chandler and Herman Daems (eds) Managerial Hierarchies: Comparative Perspectives on the Rise of the Modern Industrial Enterprise (Harvard University Press, 1980) 9, 35. 13 Jeffrey N. Gordon, 'The Rise of Independent Directors in the United States, 19502005: Of Shareholder Value and Stock Market Prices' (2007) 59 Stanford L Rev 1465, 1511. 
proceedings against three of Penn Central's outside directors, settled numerous cases involving allegations of corporate corruption by accepting undertakings from the companies involved to create a board level audit committee and appoint additional "outside" (nonexecutive) directors and "bullied" "14 the New York Stock Exchange into requiring listed companies to have audit committees composed of independent directors.

A 1980 SEC staff report based on the 1977 corporate governance hearings refrained from recommending legal reform concerning board structure or related issues. ${ }^{15}$ Two bills, however, were introduced to Congress in 1980 that proposed mandating a major governance role for independent directors as part of an effort to prompt corporations to function in more democratic and accountable ways. ${ }^{16}$ Interest in corporate governance also grew outside Washington DC, especially in the legal community. Ralph Nader, Mark Green and Joel Seligman, each graduates of Harvard Law School, ${ }^{17}$ published in 1976 Taming the Giant Corporation, which offered the earliest available detailed theorization of the term "corporate governance" and advocated imposing on directors a wide range of oversight responsibilities as well as recommending that local communities be given the opportunity to vote on corporate activities that could create health hazards. ${ }^{18}$ The American Law Institute (ALI), which undertakes projects to clarify and modernize areas of the law, committed itself in principle in 1978 to address corporate governance and followed up by organizing in 1980 a

\footnotetext{
14 'The Securities and Exchange Commission' Economist (London 9 Oct 1976) 80.

15 Securities and Exchange Commission, Staff Report on Corporate Accountability (U.S Government Printing Office, 1980), 34.
}

16 Protection of Shareholders' Rights Act, S. 2567, 96 ${ }^{\text {th }}$ Congress, 2d Sess., 126 Congressional Record S3754; Corporate Democracy Act of 1980, HR 7010, $96^{\text {th }}$ Congress, $2 \mathrm{~d}$ Sess.

17 Robert M. Smith, 'Nader Group Urges the Federal Chartering of Big Corporations' New York Times (New York, 25 January 1976) 28. Seligman went on to become a law professor.

18 Ralph Nader, Mark Green and Joel Seligman, Taming the Giant Corporation (WW Norton \& Co, 1976). 
conference on the topic co-sponsored by the American Bar Association and the New York Stock Exchange. Media coverage accelerated accordingly. ${ }^{19}$

\section{Corporate Governance Bypasses Britain (Temporarily)}

Hugo Young, a prominent U.K. political commentator, said of "governance" in a review of a 1976 book by the prominent Labour politician Harold Wilson entitled The Governance of Britain that "it is a word devoid of modern meaning or use," had a "Chaucerian ring" and a " $14^{\text {th }}$ century...heyday". ${ }^{20}$ Young, in making these observations, presumably (and understandably) was unaware that the term "corporate governance" was gaining a foothold across the Atlantic as a focal point for concerns about managerial accountability. On the other hand, Barry Barker, secretary and chief executive of the U.K. Institute of Chartered Secretaries and Administrators (ICSA), acknowledged a few years later both the antiquarian origins of the term "governance" and the recent emergence of the term in the U.S. corporate context, saying

"Governance is a Middle English word which the Americans have brought back to us in the expressive phrase 'corporate governance' - the purposes and method of how we structure and control our companies large and small." 21

19 According to the ProQuest Historical Newspaper database the number of times the phrase "corporate governance" was mentioned in major U.S. newspapers (Baltimore Sun, Boston Globe, Chicago Tribune, Christian Science Monitor, Los Angeles Times, New York Times, Philadelphia Tribune, Pittsburgh Courier, Wall Street Journal and Washington Post) was zero in 1970 and 1971, one in 1972, zero in 1973, 1974 and 1975, one in 1976, 16 in 1977 and 41 in 1978.

20 Hugo Young 'The Lessons of a Prime Minister' Sunday Times (London, 24 October 1976) 41, reviewing Harold Wilson, The Governance of Britain (Weidenfeld \& Nicolson, 1976). See also Donald Brydon, 'More Dialogue Between Boards and Shareholders is Needed' Independent (London, 11 February 1991) 11 ("When Harold Wilson wrote his memoirs The Governance of Britain many of us had to check the meaning of the archaic word 'governance'..')

21 Barry Barker, 'Foreword' in Kenneth Midgley (ed), Management Accountability and Corporate Governance (Macmillan, 1982), vii (foreword dated August 1980). 
Barker made his observations concerning the lineage of the term "corporate governance" in the foreword to a 1982 book publishing papers presented at the ICSA's 1979 annual conference under the theme "Corporate Governance and Accountability". ${ }^{22}$ The 1979 conference and 1982 volume conceivably could have been part of a surge in interest in corporate governance in Britain similar to that the United States had been experiencing. This was not the case.

Robert Tricker, in a 1984 book focusing on the U.K. entitled Corporate Governance observed "Scant attention has been paid to governance in the British company." 23 The fact that up to 1985 the term "corporate governance" had only ever been mentioned in the Times newspaper in a single 1978 article bore out Tricker's observation. ${ }^{24}$ While Sir Adrian Cadbury subsequently said he "regarded Bob Tricker as the father of corporate governance since his 1984 book introduced me to the words corporate governance" ${ }^{25}$ the book did not change the situation markedly. The phrase "corporate governance" was not used at all in the Guardian, the Economist and the Observer until 1989, 1990 and 1991 respectively. ${ }^{26}$

Even the Financial Times, which offers the most thorough U.K. newspaper coverage of British and international business, largely ignored corporate governance in the 1980s. The term first appeared in that paper in a May 1978 article on the growing prominence of outside

22 ibid.

23 R.I. Tricker, Corporate Governance (Gower 1984), 9.

$24 \quad$ Cheffins (n 2) 57.

25 Bob Tricker, Corporate Governance: Principles, Policies, and Practices, $3^{\text {rd }}$ ed. (OUP, 2015), book cover "blurb".

$26 \quad$ Cheffins (n 2) 57 (Economist); Mary Brasier, 'US-Style Proxy War Looks Set to Spread to British Companies', Guardian (London, 22 June 1989) 15; Maurice Gillibrand, 'Accountability is the Key to Wider Share Ownership' Observer (London, 19 May 1991) 30 (search conducted using the ProQuest Historical Newspaper database). 
directors in U.S. public companies. ${ }^{27}$ "Corporate governance" was then only mentioned 18 times in the 1980s, less than half as often as in 1990 alone (Figure 1).

Figure 1: “Corporate Governance" "hits”, Financial Times, 1970-1990

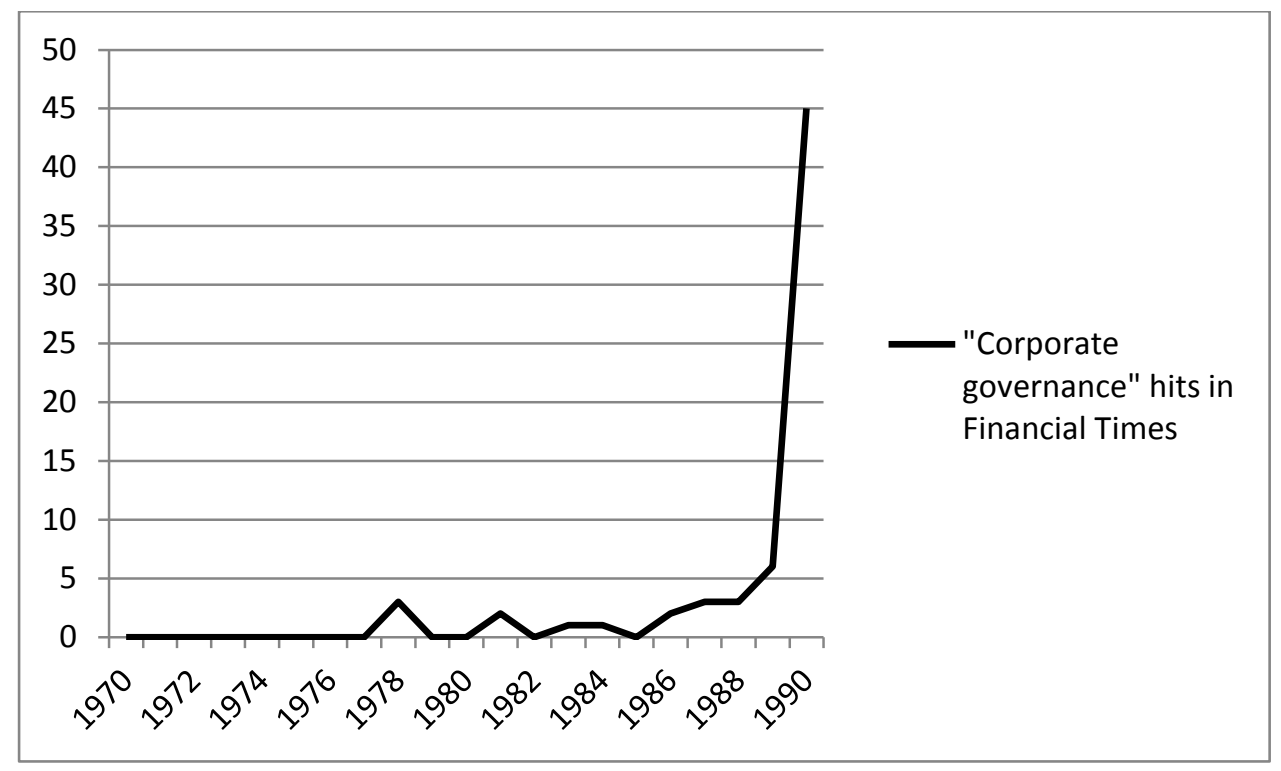

Source: Gale Cengage Financial Times Historical Archive

Why Was Scant Attention Paid to Corporate Governance in the U.K. Prior to the 1990s?

Britain and the United States obviously differ in many ways. In contrast, however, with most other countries they share an "outsider/arm's-length" system of ownership and control where larger public companies typically lack a "core" shareholder capable of exercising "inside" influence. ${ }^{28}$ Correspondingly, in both Britain and the U.S. managerial "agency costs" generated by inattentive or self-serving executives unconstrained by apathetic

$27 \quad$ Stewart Fleming, 'The Outsiders Who Are Taking Over American Boardrooms' Financial Times (London, 15 May 1978) 11 (search conducted using Gale Cengage Financial Times Historical Archive).

28 Cheffins (n 6) 5. On other similarities relevant to corporate governance, see Bonnie G. Buchanan et al., 'Shareholder Proposal Rules and Practice: Evidence from a Comparison of the United States and United Kingdom' (2012) 49 Amer Bus LJ 739, 751. 
shareholders constitute the major potential governance risk whereas elsewhere the core corporate governance concern is that dominant shareholders will exploit outside investors. ${ }^{29}$

Why, despite having similar corporate governance priorities, did Britain fail to experience until the early 1990s the sort of surge in interest in corporate governance the U.S. experienced in the 1970s? A total lack of awareness that corporate governance was an issue in the U.S. was not the reason. As we have seen, ICSA organized a corporate governancethemed conference in 1979 and the term was mentioned occasionally in the British media as the 1970 s drew to a close. ${ }^{30}$ Why, then, did corporate governance come to prominence in Britain nearly two decades later than it did in the U.S?

\section{Share ownership patterns}

A difference in chronology with the systems of ownership and control prevailing in the U.S. and the U.K. is a plausible but ultimately unconvincing explanation for corporate governance belatedly attracting attention in Britain. In the U.S. it was generally assumed by the 1950 s that it was the norm for large public companies to lack dominant shareholders. ${ }^{31}$ Some have argued, in contrast, that in Britain sizeable family blockholders were prevalent until the mid-1980s. ${ }^{32}$ Given that the nature of ownership and control within a particular country does much to shape the governance issues at stake, conceivably 1970s debates about corporate governance in the U.S. were not directly relevant to Britain.

It in fact seems unlikely that differing patterns of ownership and control account for corporate governance's somewhat belated popularity in Britain. U.S.-style diffuse share

\footnotetext{
$29 \quad$ Cheffins (n 4) x; Cheffins (n 6) 1-3, 5;

30 Text to nn 21-22.

$31 \quad$ Cheffins and Bank (n 5) 455-56.

32 See, for example, Mark J. Roe, 'Political Foundations for Separating Ownership from Control' in Joseph A. McCahery et al. (eds) Corporate Governance Regimes: Convergence and Diversity (OUP, 2002), 113, 129.
} 
ownership was the norm in Britain by the $1970 \mathrm{~s}^{33}$ and perhaps considerably earlier. ${ }^{34}$ Correspondingly, differing patterns of ownership and control fail to explain why corporate governance became topical in the U.S. in the 1970s and failed to do so at that point in Britain.

Differences in share ownership regarding institutional shareholders might indeed have been expected to make Britain more fertile ground for corporate governance debate than the U.S. in the 1970s. In the U.K., as was the case in the U.S., retail investors ill-suited to intervene in the affairs of companies in which they owned shares traditionally dominated share registers. ${ }^{35}$ In both countries institutional investors theoretically better positioned to have an impact would move to the forefront in the second half of the $20^{\text {th }}$ century but this happened considerably earlier in Britain. The proportion of shares retail investors owned collectively fell below half in the late 1960s in Britain but not until the 1990s in the U.S. ${ }^{36}$

During the 1960s and 1970s numerous observers in the U.K. flagged up the potential for institutional shareholder intervention in public companies. ${ }^{37}$ If institutional shareholders had followed up, the term "corporate governance" plausibly could have been borrowed from the U.S. to describe the contribution shareholder activism was making to managerial accountability. During the 1970s, however, institutional investors were "the sleeping giants

\footnotetext{
33 Cheffins (n 6) 11-17, 303-7.

34 James Foreman-Peck and Leslie Hannah, 'Extreme Divorce: the Managerial Revolution in UK Companies before 1914' (2011) 65 Econ Hist Rev 1217 (saying most publicly traded companies lacked a dominant shareholder as far back as the early $20^{\text {th }}$ century).

35 Cheffins (n 4) xix; Cheffins, (n 6) 126.

36 John Armour and David A. Skeel, 'Who Writes the Rules for Hostile Takeovers, and Why: The Peculiar Divergence of U.S. and U.K. Takeover Regulation' (2007) 95 Geo. LJ 1727, 1767-69.

$37 \quad$ Cheffins (n 6) 372.
} 
of British corporate life, $" 38$ meaning they would not be catalysts for the early arrival of the concept of corporate governance in the U.K.

\section{Market forces}

While share ownership patterns do little to explain why the concept of corporate governance failed to gain a foothold in Britain before the 1990s, a perception that market forces were doing an adequate job of fostering managerial accountability may well have played a role. Insurance company associations, when providing evidence in 1977 to a committee chaired by Harold Wilson that was tasked with reviewing the functioning of financial institutions, argued shareholder intervention in the affairs of public companies would be superfluous by saying "( $\mathrm{t}$ )o a large degree reliance can be placed on the essentially competitive nature of the private enterprise system which imposes strong pressures and incentives on management, and the capital markets can play their part in this."39 The reference to capital markets encompassed the scrutiny to which public offerings of shares are subject as well as takeovers, of which the insurance company associations said:

"Poor management tends to lead to lower share prices, less ability to raise cash and more vulnerability to acquisition by successful competitors. For many years now industrial managements have shown themselves to be sensitive to the message of their relative ratings in the stock market. Far more managements of public companies have taken this message and put their houses in order than have ever been taken over...."40

As the insurance company associations suggested, takeover activity can theoretically have a disciplinary effect on management, and, crucially for present purposes, can do so in a

38 David Kynaston, The City of London, vol. IV: A Club No More, 1945-2000 (Pimlico, 2001), 373.

39 Committee to Review the Functioning of Financial Institutions (Chairman, Sir Harold Wilson), Evidence on the Financing of Trade and Industry, vol. 3 (HMSO, 1977), 91. $40 \quad$ ibid 71. 
way that can marginalize corporate governance as a topic for discussion. Executives who are fearful of being dismissed as a result of a takeover offer where the bidder acquires control at an opportunistic price have a meaningful incentive to run their companies in a way that keeps the share price sufficiently high to deter unwelcome approaches. ${ }^{41}$ Correspondingly, takeovers, as with "internal” corporate governance mechanisms such as monitoring by boards, shareholder activism and incentivized executive pay, can induce management to focus on shareholders' interests. ${ }^{42}$ Arguably, then, as the insurance company associations implied, takeover activity side-lined debates on corporate governance in the U.K. by rendering internal governance mechanisms superfluous.

Merger and acquisition (M\&A) activity was in a lull in the U.K. in the late 1970s. ${ }^{43}$ The 1980s, in contrast, were marked by hectic merger activity, ${ }^{44}$ so to the extent that takeovers render corporate governance moot it was more likely to happen then. Various observers indeed remarked upon the disciplinary impact of takeovers during this era. The business editor of the Sunday Times said for instance in 1986 "The decision of the market is usually the best, if not the only, means of putting industrial assets into the hands of those most able to manage them." 45 The Financial Times similarly argued that "(a)n active market

\footnotetext{
41 Brian R. Cheffins, Company Law: Theory, Structure and Operation (OUP, 1997), 119.

42 Klaus J. Hopt, 'Comparative Corporate Governance: The State of the Art and International Regulation' in Andreas M. Fleckner and Klaus J. Hopt (eds), Comparative Corporate Governance: A Functional and International Analysis (Cambridge University Press, 2013), 3, 11-12; Philip Stiles, 'Corporate Governance' in Patrick C. Flood and Yseult Freeney (eds), Wiley Encyclopedia of Management: vol. 11 -- Organizational Behavior (Wiley, 2014), 84.

$43 \quad$ For data see Brian Chiplin and Mike Wright, The Logic of Mergers: The Competitive Market in Corporate Control in Theory and Practice (Institute of Economic Affairs, 1987), 12-18.

44 ibid.

$45 \quad$ John Jay, 'Long Live Bid Mania' Sunday Times (London, 27 July 1986) 54.
} 
in corporate control is healthy" 46 with the caveat "Britain is too dependent on takeovers as a remedy for poor industrial management." 47 Lord Hanson and Owen Green, who ran companies (Hanson and BTR respectively) that sought to create value by acquiring poorly run companies and improving shareholder returns by selling superfluous assets and imposing tough fiscal discipline, were voted the top industrialists in Britain in 1989 by their peers ${ }^{48}$ and hailed by the press as "heroes" 49 and "superstars." 50

\section{Features of 1970s U.S. debates concerning corporate governance were absent in Britain}

While the robust nature of Britain's market for corporate control in the 1980s likely helps to explain why the topic of corporate governance attracted little attention in that decade, why absent hectic deal-making in the latter half of the 1970s did the corporate governance debates occurring in the U.S. fail to resonate in Britain? The U.K. had, after all, a corporate collapse akin to Penn Central's. In 1971, Rolls Royce, the U.K.'s fourth largest employer and a synonym for British industrial quality and pride, went bankrupt, resulting in Britain's biggest bankruptcy proceeding in decades and "causing shock waves here like the Penn Central did in the U.S." ${ }^{51}$ Also, as was the case with Penn Central, managerial accountability, or lack thereof, played a role in Rolls Royce's collapse, as there were "clear

\footnotetext{
46 'Questioning Hostile Bids’ Financial Times (London, 9 November 1988) 28.

47 'Confronting City Failures' Financial Times (London, 30 January 1987) 18. See also
} Tim Jenkinson and Colin Mayer, 'The Assessment: Corporate Governance and Corporate Control' (1992) 8(3) Oxf Rev Econ Policy 1, 3 (identifying problematic features of takeovers while saying "takeovers are the most widely discussed form of corporate governance in the UK....")

$48 \quad$ Philip Beresford, 'Hanson and Green Rated Tops by Their Peers' Sunday Times (London, 5 November 1989) D20.

49 'The Industrial Heroes' Sunday Times (London, 29 March 1987) 69; Mike Smith, 'Still Room at the Top for Heroes' Financial Times (London, 23 December 1987) 13.

$50 \quad$ Peter Rogers, Margareta Pagano and Hamish McRae, 'How the Superstars Won City Support' Guardian (London, 22 January 1985) 21.

$51 \quad$ Felin Kessler, ‘Anatomy of a Fall' Financial Times (London, 8 February 1971) 1. 
danger signals which never got through to the main board" amidst "trappings of pride, arrogance, misjudgement and blind optimism.",52

Britain, on the other hand, lacked the sort of commotion over illicit payments by companies that existed in the U.S. This was not necessarily because British companies had markedly higher ethical standards than their American counterparts. There indeed were allegations that during the 1970s British arms companies were regularly paying sizeable illicit "commissions" to obtain contracts in developing countries and two executives of the Racal electronics group were convicted for taking and paying bribes in relation to tank radios destined for Iran. ${ }^{53}$ The nature of securities regulation, however, meant the corruption in U.S. companies would have governance ramifications in a way that illicit practices in which U.K. companies might have engaged would not.

One difference was the law governing disclosure by public companies. Federal securities regulation in place in the U.S. placed companies which had made illicit payments under an onus to disclose the practices in a way U.K. companies legislation did not, prompting some to argue that the law should be amended in Britain. ${ }^{54}$ Moreover, the U.K. lacked an equivalent to the SEC ${ }^{55}$ which proved adept at maximizing the leverage the disclosure rules provided to put corporate governance in the spotlight.

The SEC got the ball rolling in the U.S. by launching a handful of civil cases against public companies where there was independent evidence of illicit payments, alleging that the

$52 \quad$ Peter Wilsher, 'Where Was Whitehall When Rolls' Light Went Out?” Sunday Times (London, 5 August 1973) 50. See also Peter Rodgers, 'Rolls Chiefs' Angry Replies' Guardian (London, 3 Aug 1973) 1.

$53 \quad$ 'It's Official' Economist (London, 12 Nov 1977) 78; 'Where Bribery is an Accepted Way of Life' Guardian (London, 22 Jan 1978) 3.

54 'Bribes: The Next Step' Sunday Times (London, 22 May 1977) 16.

$55 \quad$ 'Who is Business' Keeper?' Economist (London, 23 Dec 1972), 56; Alexander Johnston, 'The City Can Look After Itself' Sunday Times (London, 6 May 1973), 63. 
corruption resulted in falsification of financial statements. ${ }^{56}$ Having signalled its intent in this way, the SEC established a voluntary disclosure program under which companies could report questionable payments without providing details on the recipients. ${ }^{57}$ Approximately 350 companies came forward, ${ }^{58}$ and the way that the SEC got a large number of prominent firms to own up commanded respect and enhanced its reputation as a regulator. ${ }^{59}$ The stage correspondingly was set effectively for the SEC to bring corporate governance on to the official agenda by orchestrating board-related settlements with firms admitting to questionable payments, by holding the 1977 hearings on corporate governance and by having chairman Harold Williams speak widely on the need for improvements on the governance front. $^{60}$

The industrial democracy distraction

While the nature of securities regulation likely helps to explain why corporate governance did not come on to the agenda in Britain in the 1970s in the same way it did in the U.S., the nature of discourse concerning the board structure of large companies was also important. In the early 1970 s, with interest in the concept of corporate governance poised to take off in the U.S., there was in the U.K. high-level debate on governance-related issues without explicit reference to corporate governance. Sir Brandon Rhys Williams introduced private member bills in multiple sessions of Parliament that would, if enacted, have required larger public companies to have at least three non-executive directors on the board. ${ }^{61}$ These

$56 \quad$ Michael C. Jensen, 'SEC to Continue Action Against Business Payoffs' New York Times (New York, 18 June 1975) 74.

$57 \quad$ 'SEC May End Disclosures Plan’ Financial Times (London, 8 March 1977) 6.

58 ibid.

59 'The Securities' (n 14).

$60 \quad$ Text preceding n 14; Cheffins (n 2) 48.

61 John Parkinson, 'Evolution and Policy in Company Law: The Non-Executive Director' in John Parkinson, Andrew Gamble and Gavin Kelly (eds), The Political Economy 
measures had no chance of becoming law ${ }^{62}$ but the Conservative government of the time was not entirely unsympathetic. It indicated that the way forward was to have matters considered in proper context by a committee the Confederation of British Industry (CBI) established in 1972 to investigate means for improving the accountability of management. ${ }^{63}$ The Watkinson Committee (the committee was chaired by Cadbury Schweppes chairman Lord Watkinson) reported in 1973, with the centrepiece of its report being a 12 item non-binding Code of Corporate Conduct that acknowledged that larger public companies should have nonexecutive directors on the board charged with monitoring the executives. ${ }^{64}$ Government White Papers issued in 1973 and 1977 similarly accepted that non-executive directors could beneficially increase the element of independence and objectivity in the boardroom but refrained from recommending that their appointment be mandatory. ${ }^{65}$

It might have been thought that with non-executives being a topic for debate in the U.K. in the 1970s the term "corporate governance" would have travelled across the Atlantic to Britain as a handy catch phrase. However, during this period a topic peripheral to the

of the Company (Hart, 2000), 233, 251; Brandon Rhys Williams, 'Fiddling With Law While Companies Burn' Sunday Times (London 7 March 1976) 55.

62 'Europe's Recipe for the Boardroom' Financial Times (London, 3 January1973) 13 (indicating the bill introduced in 1972 failed to reach the report stage); Richard Evans, 'Company Bill Debate on July 20' Financial Times (London, 28 June 1973) 12.

$63 \quad$ Parkinson (n 61) 252.

64 Michael Blanden, 'Profit Motive Strongly Defended' Financial Times (London, 25 November 1973) 31 (providing a detailed summary of the report); see also Geoffrey Owen, Evolution or Revolution? Changes in Britain's Boards of Directors from 1960 to 2010 (Spencer Stuart, 2010), 29.

$65 \quad$ Parkinson (n 61) 252; Department of Trade, Company Law Reform (Cmnd 5931) (HMSO, 1973), para. 61; Department of Trade, The Conduct of Company Directors (Cmnd. 7037) (HMSO, 1977), paras 19-20. 
initial surge of interest in corporate governance in the U.S. monopolized attention in Britain.

This was industrial democracy. ${ }^{66}$

A Christian Science Monitor columnist observed in 1977, "In many countries of Europe, but distinctly not the United States, workers are demanding, and getting, a larger voice in the decisionmaking process that makes their company run." ${ }^{97}$ As the 1970s began, Britain was not one of those European countries. Employee involvement in corporate decision-making had barely registered as an issue in the U.K. as the 1970 s got underway. ${ }^{68}$ However, in 1973 Labour leader Harold Wilson said "we are at the beginning of a social revolution in this sphere." ${ }^{, 69}$ Britain's joining the European Union, then known as the European Economic Community (EEC), was a catalyst.

In the late 1960s the EEC began to promulgate measures designed to harmonize company law in all of its Member States. ${ }^{70}$ Britain, when it joined the EEC in 1973, became

66 On industrial democracy being peripheral (if not entirely irrelevant) in the U.S. in the 1970s, see, for example, Richard L. Strout, 'Hard Hat Jobs on Corporate Boards' Christian Science Monitor (Boston, 1 February 1980) 23 (saying when the president of the United Auto Workers union secured a seat on the board of troubled auto manufacturer Chrysler that could be a "first step on the moon in the barren landscape of America's system of industrial government.") Subsequently, employee rights and voice would become topics quite often discussed in corporate governance terms. See, for example, Marc Goergen, International Corporate Governance (Pearson, 2012), 172-90.

67 Harry E. Ellis, 'Workers on the Board: Productivity Help or Hindrance?' Christian Science Monitor (Boston, 18 May 1977) 14. The idea of employee directors did attract the attention, however, of some academics. See, for example, Philip I. Blumberg, 'Reflections on Proposals for Corporate Reform Through Change in the Composition of the Board of Directors: "Special Interest" or "Public Interest" Directors' (1973) 53 Boston Univ L Rev 547.

68 Robert Heller, 'Why the CBI Beefs at Bullock' (London, 15 May 1977) 20. For an early departure from the trend, see Vincent Hanna, 'How Much of a Say Should the Workers Have?' Sunday Times (London, 22 March 1970) 12

69 Quoted in Jeremiah J. O'Connell, 'Corporate Governance: The European Challenge' in W. Michael Hoffman, Jennifer Mills Moore and David A. Fedo (eds), Governance and Institutionalizing Ethics: Proceedings of the Fifth National Conference on Business Ethics (Lexington Books, 1983), 49, 50.

70 Vanessa Edwards, EC Company Law (Oxford University Press, 1999), 6, 13, 16. 
obliged to implement those measures in force. In 1972 the European Commission issued a draft Fifth Directive which, if adopted, would have required Member States to promulgate mandatory rules regarding the internal structure and decision-making processes of public limited companies, including the organization of the board. ${ }^{71}$ The 1972 draft was structured to require companies affected to have a two-tier board where a managing organ made up of executive directors would run the company while being monitored by a supervisory organ made up of non-executive directors, including representatives of the employees. ${ }^{72}$

The board structure contemplated by the draft Fifth Directive was radically different from that which was standard in Britain. The board in U.K. public companies of the early 1970s was a unitary rather than two-tier body, there was no tradition of employee directors, a substantial minority of large companies did not have a single non-executive director and in those companies with non-executives these directors typically found themselves in a minority of one-quarter to one-third. ${ }^{73}$ Correspondingly, possible implementation of the Fifth Directive was for many in Britain an alarming prospect that quickly dominated analysis of board structure ${ }^{74}$ likely leaving in the process little room for discussions of corporate governance occurring in the U.S. to influence debate.

A 1974 Financial Times report on British boards said 'Probably no single issue has caused more worry than the prospect of being obliged to conform to the German or Dutch

$71 \quad$ COM (72) 887 final, 18 July 1972; [1972] JO C131/49.

$72 \quad$ Edwards (n 70) 388.

73 Owen (n 64) 22-24; The Board of Directors: A Survey of its Structure, Composition and Role (British Institute of Management, 1972), 2, 10; John Trafford, 'Europe's Recipe for the Boardroom' Financial Times (London, 3 January 1973) 13.

74 See, for example, Martin Routh, 'Directors See No Benefit in Two-Tier Boards' Financial Times (London, 18 April 1973) 38; 'EEC “Adds Urgency” to Company Reform' Guardian (London, 2 November 1973) 20; Clive Schmitthoff, 'Company Structure and Employee Participation in the EEC - The British Attitude' (1976) 25 Int'l Comparative LQ $611,614$. 
model of a two-tier board....,75 As radical as the Fifth Directive might have been for British businesses if the EEC had adopted it (the EEC never did), ${ }^{76}$ it would soon be overshadowed by a homebred worker-director initiative that further marginalized from a British perspective fledgling discussions of corporate governance in the U.S. The distraction was understandable. Distinguished company law academic Dan Prentice argued in 1978 that the proposals on the agenda to provide for employee representation in the boardroom would, if implemented fully, "transform the prevailing legal relationship between shareholders and the board, and between the board and corporate management." $" 77$ The proposals, moreover, were sufficiently high on the policy agenda to "enrage" 78 the British business community and to prompt newspaper speculation about a "new industrial revolution",79 and a "jolt to class balance." $" 80$

A 1977 report by the Committee of Enquiry on Industrial Democracy, chaired by Lord Bullock, became the focal point for debate on employee representation on boards in Britain. $^{81}$ The Labour government, which had committed itself in its October 1974 election manifesto to a radical extension of industrial democracy in the private sector, ${ }^{82}$ announced in

75 John Temple Lang, 'Supervision is the Key' Financial Times (London, 20 December 1974) 15.

76 Stefan Grundmann, European Company Law: Organization, Finance and Capital Markets (2d ed) (Intersetia, 2012), 249.

77 D.D. Prentice, 'Employee Participation in Corporate Government - A Critique of the Bullock Report' (1978) 56 Can Bar Rev 277, 285.

78 Bernard D. Nossiter, 'British Business is Enraged by Promise of Worker Power' Wash Post (Washington 27 January 1977) A20.

79 'Is This the New Industrial Revolution?' Sunday Times (London, 30 January 1977), 53; see also John Elliot, 'Worker Directors: A Plan for Radical Industrial Change' Financial Times (London, 14 December 1976) 16.

$80 \quad$ John Elliott, ‘A Jolt to Class Balance’ Financial Times (London, 27 January 1977) 18.

81 Report of the Committee of Inquiry on Industrial Democracy (Lord Bullock, chair), Cmnd 6706 (HMSO, 1977).

82 'Programme for Action' Guardian (London, 17 September 1974) 8; John Elliott, Conflict or Cooperation: The Growth of Industrial Democracy (Kogan Page, 1978), 216. 
1975 a commitment to legislating in this area and established the Bullock Committee to prepare the ground. ${ }^{83}$ The Financial Times said as the Bullock Committee was deliberating that worker directors were "on the way - sooner or later". ${ }^{44}$ The majority report of the Bullock Committee recommended that with companies with a staff of 2,000 or more the employees should, on application by a recognized trade union, have the opportunity to vote whether to introduce, by way of a combination of union nominees and "co-opted" directors (directors agreed upon by the union and the shareholders) equal rights of representation on the board with shareholders. ${ }^{85}$

Lord Bullock maintained at the time the Bullock Report was issued "We are at the beginning of a change which will sweep to all countries of Europe" ${ }^{\nexists 6}$ and the Secretary of State for Trade reaffirmed the government's commitment to extending industrial democracy radically. ${ }^{87}$ Barron's, the U.S. business newspaper, said there at least would be a compromise between management and unions "with both sides shaking hands over the mangled corpse of the shareholder." 88 In the face, however, of strong opposition from the business community and a lack of consensus among trade unionists enthusiasm for industrial democracy waned among senior government figures. ${ }^{89}$ Proposals set out in a 1978 White Paper correspondingly were considerably diluted as compared to the majority Bullock

83 Ben Clift, Andrew Gamble and Michael Harris, 'The Labour Party and the Company' in Parkinson, Gamble and Kelly (n 61), 51, 76.

84 John Elliott, 'Worker Directors on the Way - Sooner or Later' Financial Times (London, 2 July 1976) 16; see also 'Bullock: Historic Tide' Observer (London, 30 January 1977) 12.

85 For more detailed summaries of what was proposed, see Prentice (n 77) 285-86; Elliott (n 82) 234-37.

86 Peter T. Kilborn, 'Britain Considers Voice for Workers in Management' New York Times (New York, 27 January 1977) 3.

$87 \quad$ Nossiter (n 78).

$88 \quad$ 'Boardroom Revolution?' Barron's (New York, 14 February 1977) 57.

89 Elliott (n 82) 241-49; John Elliott, 'Pause for Second Thoughts on Bullock', Financial Times (London, 28 July 1977) 20. 
report. $^{90}$ The Labour government, struggling to cope with events that culminated in a 197879 “winter of discontent" and electoral defeat in 1979, did not table legislation to implement the White Paper. ${ }^{91}$

The Financial Times predicted prior to the 1979 election that the issue of industrial democracy would not go away whatever the result. ${ }^{92}$ Matters worked out differently when Margaret Thatcher's Conservatives won convincingly, with the Labour Party abandoning even a rhetorical commitment to Bullock-style industrial democracy after the early 1980 s. $^{93}$ Nevertheless, the intense debate over employee representation on boards that was occurring as the concept of corporate governance emerged from obscurity in the U.S. likely helps to explain why the same did not occur across the Atlantic. As the Deputy Secretary of the Department of Trade said at a 1981 U.S. conference on corporate governance, "Corporate governance is not a term heard in Europe....The major item of debate for years has been industrial democracy." 94

\section{Corporate Governance Arrives in Britain}

While corporate governance was rarely mentioned in Britain for nearly two decades after the initial surge in interest in the concept in the United States, matters changed dramatically as the 1990s began. In 1990, the year before the Cadbury Committee was

\section{$90 \quad$ Keith Harper, 'After Bullock: The Voluntary Way to Industrial Democracy'} Guardian (London, 24 May 1978) 17 ("falls far short of the proposals put forward in the Bullock Report....”); Adrian Hamilton and Robert Taylor, 'The Long Road from Bullock to Market' Observer (London, 28 May 1978) 14.

$91 \quad$ Clift, Gamble and Harris (n 83) 80.

92 'Democracy in Industry' Financial Times (London, 24 April 1979), 24.

93 Clift, Gamble and Harris (n 83) 80.

94 P.A.R. Brown, 'Corporate Governance: A Survey of Foreign Developments' in C.J. Huizenga (ed), Proceedings of Corporate Governance: A Definitive Exploration of the Issues (UCLA Graduate School of Management, 1983), 207, 207. See, though, R.I. Tricker, The Independent Director: A Study of the Non-Executive Director and of the Audit Committee (Tolley, 1978), 1 (saying Bullock "focused widespread attention on the governance of the company"). 
established, press coverage of corporate governance began in earnest (Fig. 1) and theoretical commentary was starting to accumulate. ${ }^{95}$ Readers of 1990 articles on non-executive directors in the Financial Times were told that "Corporate governance is one of those themes of the 1990 s that is growing in intensity" 96 and that "There is ample evidence that investors are concerned about the state of corporate governance in the U.K." ${ }^{97}$ John Redwood, the corporate affairs minister, said the same year he supported calls by institutional shareholders for "truly independent" non-executive director representation on boards and added that "Better corporate governance does require the remodelling of some boards of directors." $" 98$

In 1991, an investment manager was quoted in the Independent to the effect "governance...would become one of the fashionable words of the 1990s". 99 The Guardian similarly referred in 1992 to "the current craze for corporate governance issues."100 The Financial Times likewise remarked upon "the public fascination with corporate governance" 101 and the Observer suggested that "the matter of corporate governance will be

95 See, for example, Jonathan Charkham, 'Corporate Governance and the Market for Corporate Control of Companies’ (1989) Bank of England Panel Paper No. 25; Evan Davis and John Kay, 'Corporate Governance, Takeovers and the Role of the Non-Executive Director', Bus Strategy Rev, Autumn 1990, 17.

96 Simon Holberton, 'Where the Power Lies', Financial Times (London, 21 December 1990) 14.

97 Simon Holberton, 'Why the Ideal Board is so Elusive' Financial Times (London, 4 July 1990) 10.

98 Richard Waters, 'Minister Backs Calls to Reform Board Structure' Financial Times (London, 8 December 1990) 4.

99 Brydon (n 20).

100 Mark Milner, 'Boardroom Reform Under the Spotlight' Guardian (London, 29 July 1992) 11.

101 Norma Cohen, 'Cadbury Responds to CBI Hostility' Financial Times (London, 14 September 1992) 10. 
the issue for public companies as we hurtle towards 2000."102 A massive increase in media coverage reflected the changed circumstances (Fig. 2).

Figure 2: “Corporate Governance" "hits”, Financial Times \& Guardian/Observer 1990-2000

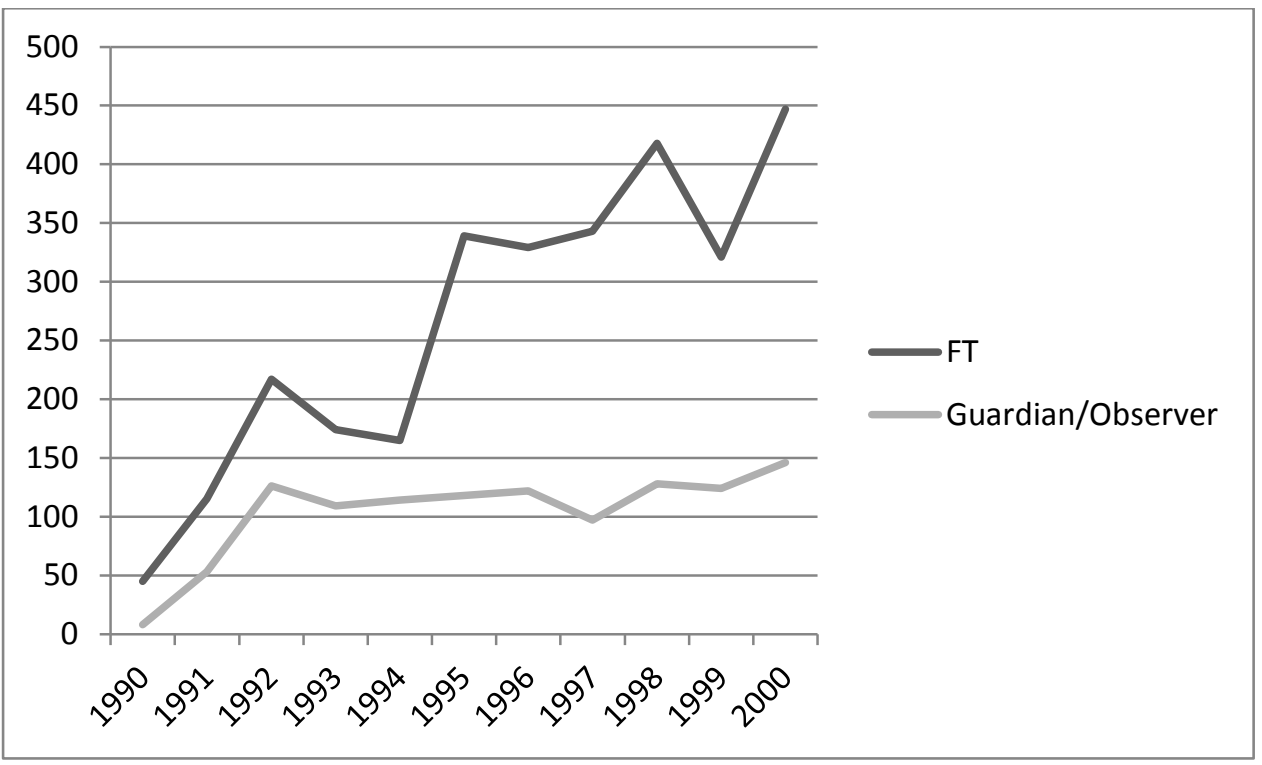

Source: Gale Cengage Financial Times Historical Archive/ProQuest Historical Newspaper Database

The Cadbury Committee and the Rise of Corporate Governance

Why did corporate governance achieve prominence in Britain when it did at the start of the 1990s? The work of the Cadbury Committee stands out as the most obvious catalyst for the newfound interest in the topic. Cadbury's impact indeed was substantial, as we will see now. The remainder of the paper will show, however, that due to various trends relating to publicly traded companies the concept of corporate governance likely was destined to rise to prominence in Britain in the early 1990s even in the absence of Cadbury.

\section{The Cadbury Committee in Operation}

102 Lindsay Vincent, 'Hard Nut in the Boardrooms' Observer (London, 6 December 1992) 36 (emphasis in original). 
The Cadbury Committee was launched in May 1991 by the London Stock Exchange, key members of the accountancy profession and the Financial Reporting Council, an independent regulator backed by accountancy organizations and the U.K. government. ${ }^{103}$ The Committee's sponsors were concerned about an erosion of confidence in the standard of disclosure in published company accounts and in the ability of auditors to meet the expectations of users of corporate financial statements. ${ }^{104}$ The Committee also had a mandate to take into account broader corporate governance issues, including the responsibilities of executive and non-executive directors to review and report on corporate performance and foster communication between the board, shareholders and other stakeholders. ${ }^{105}$ Accordingly, institutional investors and the corporate sector, in the form of a council member of the CBI, were represented on the Committee. ${ }^{106}$

The Cadbury Committee agreed quickly after its establishment that it would generate a code of best practice. ${ }^{107}$ By the time the Committee issued a report and draft code of corporate governance best practice in May 1992 it had settled on the idea that companies should publish a statement of compliance with its code as a continuing obligation of listing on the London Stock Exchange. ${ }^{108}$ In December of that year the Cadbury Committee issued the final version of its Code of Best Practice and an accompanying report which provided the

\footnotetext{
$103 \quad$ Spira and Slinn (n 8) 45-46, 53; Cheffins, Company (n 41) 373, 641.

$104 \quad$ Spira and Slinn (n 8) 45; Cheffins, Company (n 41) 373.

105 Simon Holberton, 'DTI Will Back In-Depth Review of Companies', Financial Times (London, 31 May 1991) 7.

$106 \quad$ Spira and Slinn (n 8) 47.

107 ibid 61.

108 Margaret Park, 'A Code to Put Firms to Shame' Sunday Times (London, 31 May 1992) 11. There was press speculation on the point a couple of months beforehand: Norma Cohen, 'Cadbury Panel May Invoke SE Listing Rules' Financial Times (London, 16 March 1992) 11.
} 
rationale for the Committee's recommendations. ${ }^{109}$ The Stock Exchange followed up shortly thereafter by introducing what became known as the "comply or explain" obligation in its listing rules. ${ }^{110}$ Listed companies correspondingly became obliged either to adhere fully to the provisions in the Code of Best Practice or explain any non-compliance. ${ }^{111}$

Critics argued that the Cadbury Code and the accompanying report offered guidance that was too vague and insufficiently ambitious and that improvement would be incremental because adherence to the guidelines was not required by law. ${ }^{112}$ Such pessimism proved to be largely unwarranted. ${ }^{113}$ Non-executive directors had in the wake of the issuance of the Cadbury Code leverage they lacked previously and listed companies treated failing to adhere to Code of Best Practice provisions as something to be avoided. ${ }^{114}$ In the foreword to a Cadbury Committee 1995 report on compliance with the Code, Sir Adrian Cadbury characterized the response as "heartening" and said "Real progress in raising governance standards is being made...."115 A committee chaired by Sir Ronald Hampel with a remit of reviewing the impact of the Cadbury Report and a 1995 report on executive pay by a committee chaired by Sir Richard Greenbury ${ }^{116}$ said in its 1998 report of Cadbury that it was

109 Committee on the Financial Aspects of Corporate Governance, Code (n 7); Committee on the Financial Aspects of Corporate Governance, Report (n 7).

110 Neither the Code of Best Practice nor the accompanying report actually used the term "comply or explain": Spira and Slinn (n 8) 171; Donald Norberg and Terry McNulty, 'Creating Better Boards Through Codification: Possibilities and Limitations in UK Corporate Governance' (2013) 55 Bus Hist 348, 362.

111 Stock Exchange, The Listing Rules (London Stock Exchange, 1993), para. 12.43 (j).

112 For a summary of the criticisms, see Cheffins (n 41) 644.

$113 \quad$ Spira and Slinn (n 8) 191; Owen (n 64) 41.

114 Cheffins (n 41) 648-49.

115 Committee on the Financial Aspects of Corporate Governance, Compliance with the Code of Best Practice (Gee, 1995), 8.

116 Greenbury Committee, Directors' Remuneration: Report of a Study Group Chaired by Sir Richard Greenbury (Gee, 1995). 
"generally accepted that implementation of the code's provisions has led to higher standards of governance and greater awareness." 117

The work the Cadbury Committee did was influential internationally as well as domestically. While most countries with well-developed equity markets now have in place a widely recognized code or set of corporate governance principles and such codes are often backed by a "comply or explain" regime, ${ }^{118}$ the Cadbury Code was the pioneer and as such quickly captured attention elsewhere. The 1998 Hampel Report said that Cadbury "struck a chord in many overseas countries; it has provided a yardstick against which standards of corporate governance in other markets are being measured." 119 A Swiss company law expert said the same year "it is hard to imagine today how any discussion of Corporate Governance could by-pass the Cadbury Report and the corresponding Code of Best Practice."120 The Cadbury Code thus qualified as the 1990s drew to a close as "the world leader" with respect to corporate governance issues. ${ }^{121}$ Sir Adrian Cadbury himself "rapidly became the public face of corporate governance around the world, travelling widely to address conferences and spending time giving interviews to journalists from publications ranging from local newspapers to widely read practitioner journals." ${ }^{, 122}$

Why did the Cadbury Committee's deliberations have a substantial impact?

117 Committee on Corporate Governance (chaired by Ronald Hampel), Report (Gee, 1998), 9.

118 Tricker (n 25) 140; Hopt, (n 42) 17, 23, 98; OECD, Corporate Governance Factbook (OECD, 2015), 7, 11.

119 Committee on Corporate Governance (n 117) 8.

120 Peter Böckli, 'Switzerland' A.R. Pinto and G. Visentini (eds), The Legal Basis of Corporate Governance in Publicly Held Corporations: A Comparative Approach (Kluwer, 1998), 195, 198.

121 Gerald Vinten, 'Corporate Governance: A UK/USA Comparison' (1998) 19(6) Credit Control 18, 18-19.

$122 \quad$ Spira and Slinn (n 8) 178. 
Why was the Cadbury Committee so influential? Over the long haul, the novelty and effectiveness of its Code of Best Practice were pivotal. As we have just seen, dealing with corporate governance by way of a code backed by "comply or explain" not only was innovative but had a greater impact on public company behaviour than many anticipated. In the short-term, events occurring concurrently with the Cadbury Committee's establishment and deliberations put Cadbury - and corporate governance -- in the spotlight to an unanticipated degree.

The launching of the Cadbury Committee did not in and of itself have a galvanizing effect. A newspaper columnist identified the name of the committee as a major obstacle, saying of those in charge of naming the Committee on the Financial Aspects of Corporate Governance "You could not have chosen better if you wanted to kill your report stone dead."123 Sir Adrian Cadbury indeed was wrong footed by the attention the Committee would subsequently garner, saying in September 1992 of himself and the other Committee members "When we were set up, we didn't expect to be the centre of all of this attention." 124

A recession the U.K. was experiencing was one event occurring just prior to and during the course of the Cadbury Committee's deliberations that drew attention to its work. As Cadbury himself noted prior to the issuance of the December 1992 final report challenging economic conditions affecting Britain had been exposing managerial weaknesses the buoyant economy of the late 1980s had masked. ${ }^{125}$ The fact that executive pay was rising

\footnotetext{
123 Clare Dobie, 'Diverted by Detail' Independent (London, 8 August 1992) 19. 124 Cohen (n 101).

125 ibid.; see also Alex Brummer, 'Stirring Up Lifestyles of the Company Directors' Guardian (London, 30 May 1991) 11; Michael Fowle, 'Directors, Not Auditors, Govern Companies' Financial Times (London, 13 June 1991) 12; Roger Trapp, 'Much Ado About a Little' Independent (London, 31 May 1992) 11.
} 
substantially as profits fell due to the economic downturn reinforced the idea that not enough was being done to hold top executives to account in leading U.K. companies. ${ }^{126}$

A wave of corporate scandals occurring contemporaneously with the Cadbury Committee's formation and operation was an even more important reason Cadbury received unanticipated attention. The Cadbury Report implicitly acknowledged the point in its final report, saying "Had a Code such as ours been in the existence in the past, we believe that a number of the recent examples of unexpected company failures and cases of fraud would have received attention earlier." "127 The 1990 collapse of the Polly Peck International plc food and consumer electronics group helped to set the scene. ${ }^{128}$ Some shareholders sought shortly before Polly Peck's downfall to strengthen the company's board so it would be properly situated to deal with Asil Nadir, the company's high-profile chairman, CEO and dominant shareholder. ${ }^{129}$ These efforts failed and in October 1990 administrators were called in as shares worth $£ 2$ billion three months earlier had become worthless and Nadir stood accused of having perpetrated what to that point was "the biggest fraud in English commercial history."130

126 Lisa Buckingham, 'Up, Up, and Away' Guardian (London, 13 June 1991) 13; Simon Holberton and Christian Tyler, 'Sticky Question of Fingers in the Honeypot' Financial Times (London, 13 June 1991), Weekend FT 1; Lisa Buckingham, 'Greed Still the Boardroom Creed' Guardian (London, 2 May 1992) 38; Alex Brummer, 'Hard Centre Cadbury' Guardian (London, 2 December 1992) 18.

127 Committee on the Financial Aspects of Corporate Governance, Report (n 7) 12.

128 Brummer (n 125); Nigel Graham Maw, Lord Lane of Horsell and Michael CraigCooper, Maw on Corporate Governance (Dartmouth, 1994), 141; Ben Laurence, 'Minister Admits Bids Can Be Damaging' Guardian (London 8 December 1990), 8 (saying the corporate affairs minister had indicated that "a number of spectacular insolvencies" had prompted debates about corporate governance).

129 'Entrepreneurs and the City', Financial Times (London, 24 September 1990), 24.

130 Gareth David, 'Polly Peck: From £2 Billion to Zero’, Sunday Times (London, 28 October 1990), sec. 2, 8; Andrew Davidson, 'Scandal' Sunday Times (London, 29 October 1991) 3 . 
The following year -- the year the Cadbury Committee was launched -- was in the British business world an "unprecedented year for scandal."131 In February 1991 criminal charges were filed against Nadir, who ultimately fled Britain after being charged with stealing over $£ 100 \mathrm{~m}$ from his company. ${ }^{132}$ In July, global banking authorities, led by the Bank of England, shut down the Abu Dhabi dominated Bank of Credit and Commerce International (BCCI) amidst revelations of minimal boardroom oversight of a banking business characterized by rampant corruption, deceit and fraud. ${ }^{133}$ Most spectacularly, when press baron Robert Maxwell died suddenly in November a business empire orientated around two public companies, Maxwell Communications Corporation and Mirror Group Newspapers plc, collapsed as improper diversion of pension funds and an illegal share price support scheme came to light. ${ }^{134}$ Maxwell was subsequently described as "the greatest and greasiest crook in financial history."135 The non-executive directors of Maxwell Communications and Mirror Group Newspapers, which included some prominent former politicians, conferred respectability on the Maxwell business empire but seemingly did nothing to deter the wrongdoing. ${ }^{136}$

A Guardian columnist commenting on the release of the Cadbury Committee's final report in 1992 suggested "Mega scandals like BCCI and Maxwell...have rightly propelled the issue of corporate governance to the top of the City's agenda" " "the City" is shorthand for

\footnotetext{
131 Davidson (n 130).

132 ibid; Cheffins, Company (n 41) 613.

133 Steven Prokesch, 'Years of Problems' NY Times (New York, 6 July 1991) 1;

'Wholesale Deception to Misrepresent and Falsify' Financial Times (London, 3 August 1991) 7 .

134 Cheffins, (n 41) 612-13.

135 Robert Heller, The Naked Manager for the Nineties (Little, Brown, 1995), 87.

136 Philip Stiles and Bernard Taylor, 'Maxwell -- The Failure of Corporate Governance', (1993) 1 Corp Gov - Int'1 Rev 34, 40.
} 
London's financial district). ${ }^{137}$ The Maxwell debacle was probably the most crucial. It provided the Cadbury Committee, established a few months beforehand, with a potent justification for focusing closely on board responsibility and composition, ${ }^{138}$ topics more in the corporate governance mainstream than auditing and accounting. The scandal also meant the Cadbury Committee's findings captured attention in a manner that would not have occurred otherwise. As the Guardian said of the Committee, "(i)t is reporting at a time when public consciousness of wrongdoing in the boardroom is particularly high after the Maxwell affair."139

Based on the foregoing it might be assumed that the Cadbury Committee's work, fortified by recession, executive pay patterns and corporate scandals, was responsible for bringing the concept of corporate governance to prominence in the U.K. There can be no doubt that the Cadbury enterprise was a pivotal chapter in the history of corporate governance in Britain. There were, however, broader forces at work that meant corporate governance would have in all likelihood have risen to prominence without Cadbury.

In 1995 Gina Cole, then secretary to the Cadbury Committee, cited the publication of Codes of Conduct by the National Health Service and debates in Canada and Australia concerning adoption of "comply or explain" corporate governance arrangements as evidence "of the strong influence of the committee's work." "140 She qualified her verdict, however, observing "One cannot say that if the Cadbury Committee had not existed that these

137 Brummer, n 126.

138 Spira and Slinn (n 8) 82, 216 (noting as well, though, that the Committee's remit potentially precluded a wide-ranging governance enquiry).

139 Alex Brummer, 'Cracking the Secret Code That Helps to Shield Investors' Guardian (London, 28 May 1992) 10.

140 Gina Cole, 'The Cadbury Committee Report - Implementation and Influence' in Saleem Sheikh and William Rees, Corporate Governance and Corporate Control (Cavendish, 1995), 355, 359. 
developments, and others overseas, would not have occurred." 141 The remainder of the paper will argue that the situation was much the same for corporate governance and U.K. public companies. The Cadbury Committee's legacy was substantial. After all, the U.K. Corporate Governance Code, the successor document to the Cadbury Code of Best Practice - albeit much enlarged $^{142}$ - is currently the departure point for understanding corporate governance in Britain. Nevertheless, there was more going on with the rise of corporate governance in the U.K. than Cadbury. Trends that likely would have ensured that corporate governance would have become topical in Britain in the early 1990s without Cadbury will be identified in the remainder of the paper. Focusing on developments in the United States provides necessary context.

Corporate Governance "Grows Up" in the U.S. ${ }^{143}$

While corporate governance had moved into the spotlight in the U.S. by the late 1970s, it was unclear what the future held as the 1980s got underway. The 1970s version of "corporate governance", with nomenclature that implied that the corporation was a political structure to be governed, was potentially a poor fit in a decade when faith in markets revived and scepticism of government was growing. A political shift to the right, exemplified by Ronald Reagan's 1980 election to the presidency, took major federal corporate governance reform off the table. The ALI continued with its corporate governance project but, in the face of lobbying from the corporate sector and from law school academics examining corporate

141 ibid.

142 Financial Reporting Council, The UK Corporate Governance Code (FRC, 2014); Andrew Chambers, Chambers' Corporate Governance Handbook (Bloomsbury, 2014), 487 (indicating that while the 1992 Code of Best Practice contained only 19 "comply or explain" provisions, the 2012 version of UK Corporate Governance Code had 18 Main Principles, 25 Supporting Principles and 52 provisions):

143 On the sources drawn upon for this section of the paper, see $\mathrm{n} 10$. 
law from a new, market-oriented "law and economics" perspective, quickly retreated from proposals to endorse mandatory rules concerning board structure.

Corporate governance, however, would not be on the ropes for long. Interest in the topic never entirely flagged in the 1980s and during the 1990s corporate governance became well-entrenched in the U.S. as academic, investor and regulatory shorthand.

Correspondingly, when corporate scandals erupted in a series of major companies in the early 2000s debates about causes, effects and remedies were routinely framed in terms of governance. A takeover wave the U.S. experienced in the 1980s would help to provide corporate governance with staying power, a somewhat ironic twist given that the incentives hostile takeover activity provide to management to focus on shareholder interests can render

internal governance mechanisms superfluous. ${ }^{144}$ Dramatic changes affecting the managerial function in U.S. public companies would then in turn provide a potent rationale for corporate governance being high on the agenda in the 1990s.

The 1980s: Takeovers and Corporate Governance

A key reason why interest in corporate governance was sustained in the 1980s in the U.S. was that it became increasingly associated with shareholder interests. The shift away from the politically-tinged 1970s version of corporate governance matched up well with the zeitgeist of the market-friendly 1980s. For instance, economists who initially shunned corporate governance as a mushy irrelevance began treating internal control systems of corporations as an important research topic. A takeover wave the U.S. experienced in the 1980s played a prominent role in the reorientation of corporate governance around shareholders.

$144 \quad$ Text to $\mathrm{n} 42$. 
What became known as "the Deal Decade" was exemplified by bidders relying on aggressive, innovative financial and legal techniques to offer generous premiums to shareholders of target companies to secure voting control. The fate of publicly traded companies correspondingly hinged to an unprecedented extent on shareholder assessments of the capabilities of the incumbent management teams. Assumptions about the balance of power between management and stockholders were accordingly modified in the stockholders' favour and perceptions of corporate governance evolved in turn.

Takeovers further strengthened the association between corporate governance and shareholder interests due to institutional shareholder opposition to defensive tactics companies were adopting. During the 1980 s the institutional investors which were increasingly displacing retail investors as share owners ${ }^{145}$ generally welcomed the opportunity to sell their stock in response to a premium-priced takeover offer. This set the scene for a clash when boards of 1980s public companies began adopting poison pills and similar takeover defences to defeat unwelcome takeover bids.

Various institutional shareholders pushed back against the proliferation of takeover defences. Their struggle was an uphill one but the initial foray would help to set the stage for further governance-related activity by institutional investors. The California Public Employees Retirement System (Calpers), a massive public pension fund, was an early and vocal objector to the deployment of defensive tactics in the takeover context. It formalized its campaign in 1985 by launching the Council of Institutional Investors (CII), an association of public pension funds that would subsequently engage in high-profile lobbying for shareholder rights. 
If the same sort of pushback against takeover defences had existed in Britain in the 1980s this might have resulted in corporate governance achieving prominence earlier than it in fact did. There was, however, no parallel trend in the U.K. despite the surge in takeover activity Britain experienced. ${ }^{146}$ The law, in the form of case law rulings and anti-takeover statutes a substantial number of states had adopted, gave boards of U.S. public companies substantial scope to deploy the defensive tactics to which Calpers and other institutional shareholders objected. The position was considerably different in Britain. ${ }^{147}$ The City Code on Take-Overs and Mergers, a body of rules the Bank of England, the London Stock Exchange and influential City firms promulgated in the late 1960s to govern bids, precluded a public company from taking any "frustrating action" without shareholder consent once a takeover offer had materialized. ${ }^{148}$ Various features of U.K. company law and stock market regulation also discouraged public companies from embedding takeover defences before a bid was on the horizon. ${ }^{149}$ Correspondingly, unlike in the U.S. takeover defences would not provide in Britain any sort of catalyst for debate about shareholder rights or corporate governance more generally.

In the U.S. takeovers, in addition to sustaining, if indirectly, corporate governance's relevance in the 1980s by pushing shareholder interests up the agenda, provided a further boost when they receded in importance. The Deal Decade ended abruptly at the beginning of the 1990s, due primarily to a nascent recession and a debt market chill. The widespread deployment of defensive tactics meant hostile offers were hit particularly hard. With the disciplinary effects of takeovers having been truncated, attention turned increasingly to the

\footnotetext{
146 On takeover activity in the U.K. in the 1980s, see text to $\mathrm{n} 44$.

147 Armour and Skeel (n 36) 1733-36; Geoffrey Hughes, 'Public Share Offers in the U.S. and Britain' Financial Times (London, 31 January 1985) 8.

148 Armour and Skeel (n 36) 1736, 1758, 1760-61; Hugo Dixon, 'Plessey Rejects PoisonPill Strategy' Financial Times (London, 23 January 1989) 24.
} 
role the board of directors, shareholder activism, incentivized executive compensation and related internal governance mechanisms could and should play in keeping managers in check.

As if on cue, dismissals of CEOs at a number of prominent U.S. public companies in the early 1990s indicated that boards were becoming more vigilant. Institutional shareholders simultaneously began lobbying companies to displace a traditional "pay-for-size" bias in favour of incentive-oriented remuneration schemes, resulting in a dramatic surge in the use of equity-based pay, most prominently in the form of stock options. The trend increased the pay-to-performance sensitivity of CEO remuneration as well as setting the stage for a substantial and controversial rise in aggregate levels of managerial compensation during the 1990s.

\section{Changes to the Managerial Function}

During the managerialist era immediately following World War II corporate governance was not a high priority in the U.S. because amidst general economic prosperity egregious misbehaviour was rare among senior executives of public companies. ${ }^{150}$ The prototypical executive was a bureaucratically inclined "organization man" who subordinated personal aspirations to foster the pursuit of corporate goals. ${ }^{151}$ The paradigmatic chief executive aspired to be an industrial statesman who could successfully accommodate a wide range of constituencies rather than a charismatic leader taking bold risks.

The nature of managerial capitalism during the 1950s and 1960s does much to explain why when "organization man" was in the ascendancy executives largely stuck to the straight and narrow despite neither boards nor shareholders exercising substantial oversight. Close control risk-averse and closely regulated banks exercised over capital-raising and corporate

\footnotetext{
150 Text to nn 12-13.

151 The term "organization man" was coined in this context by William Whyte: The Organization Man (Simon \& Schuster, 1956).
} 
borrowing helped to constrain managerial ambition. Organized labour was a force to be reckoned with in numerous industries and executives frequently agreed to changes that could limit significantly their managerial prerogatives so as to promote workplace harmony. Though some companies transformed themselves into diversified conglomerates with hectic deal-making, a preference in favour of holding a steady course as long as possible was prevalent in "first mover" companies which dominated key industries and, correspondingly, the U.S. economy. The "safety-first" bias went largely unchecked by market forces due to a dearth of foreign competition and a "managed economy"152 where horizontal mergers involving firms with a sizeable market share were strongly discouraged and regulators enforced industry-wide standards in telecommunications, transport and other key sectors.

By the 1990s key precepts of the post-World War II managerialist era had been dislodged in a manner that meant U.S. public company executives both had a wider opportunity set and greater potential for failure. Under such circumstances, executive performance logically should have been doing more to dictate the fate of the companies they ran, which implied the quality of corporate governance should have been a higher priority than had previously been the case. For instance, deregulation, which commenced during the late 1970s and moved into full swing in the 1980s, increased the importance of the managerial function in firms affected. This was because the unravelling of constraints on horizontal mergers, pricing, marketing and distribution created new opportunities to generate profits while the removal of the regulatory "safety net" fostered substantial downside risk for laggards.

Changes in workplace relations in the early 1980s also bolstered the latitude executives had. Due to increasingly robust foreign competition, legal reform and difficult

152 Rakesh Khurana, From Higher Aims to Hired Hands: The Social Transformation of American Business Schools and the Unfulfilled Promise of Management as a Profession (Princeton Univ Press, 2007), 206. 
economic times union power drained away. Correspondingly, while executives in the managerialist era had to be mindful of keeping organized labour onside their counterparts in the 1990s had wide discretion to respond to technological change and intensified competition by outsourcing and downsizing.

New financial conditions further altered the managerial function. While during the 1950 and 1960s commercial and investment banks were conservative allocators of capital by the 1990s they were competing intensely for business and public companies could take advantage of a wide range of options to finance existing operations, new acquisitions and expansion plans. Improved access to finance could be a curse as well as a blessing for executives as seemingly unassailable incumbents increasingly found they were being challenged by new entrants that could readily raise capital to play "catch up".

The changing circumstances were heralded widely in the 1990s, with books such as The Death of Organization Man ${ }^{153}$ and The Transformation of Management ${ }^{154}$ emphasizing that "being a CEO 'ain't' what it used to be." ${ }^{\prime 55}$ Top management of public companies was in turn conceptualized differently. The "imperial" chief executive rose to prominence, with the definition of an effective $\mathrm{CEO}$ reputedly changing "from that of competent manager to charismatic leader." ${ }^{156}$

A consensus developed that under the new conditions chief executives could do more to influence corporate performance than used to be the case. This had significant implications for corporate governance. Having the best possible person in charge logically

\footnotetext{
153 Amanda Bennett, The Death of the Organization Man (William Morrow \& Co, 1990). 154 Mike Davidson, The Transformation of Management (Butterworth-Heinemann, 1996).

155 J. David Pincus and J. Nicholas DeBonis, Top Dog (McGraw-Hill, 1994), 15.

156 Rakesh Khurana, Searching for a Corporate Savior: The Irrational Quest for Charismatic CEOs (Princeton Univ. Press, 2002), 71.
} 
became a top priority, as did using compensation arrangements to provide executives with robust incentives to manage effectively. The growing emphasis on linking managerial pay with performance and the board-led dismissal of CEOs at various prominent U.S. public companies in the early 1990s implied there indeed was a meaningful governance response to a business environment reshaped by market and regulatory trends.

\section{Epilogue}

In the 1990s corporate governance increasingly became part of the fabric of corporate life in the United States. This did not mean that corporate governance was functioning optimally, as stratospheric executive pay increases in the 1990s and corporate scandals afflicting Enron, WorldCom and other prominent public companies in the early 2000s demonstrated. In the wake of the scandals, however, a combination of a tougher legal regime (primarily the Sarbanes-Oxley Act of 2002) ${ }^{157}$ and increased vigilance on the part of boards, shareholders and the media resulted in a "new, post-revolutionary generation of power in corporate America" exemplified by CEOs "on shorter leashes, more beholden to their boards of directors."158 The process was repeated in the banking sector in the wake of the 2008 financial crisis. Primarily due to tougher regulation by 2013 "Large banks, burned by years of scandal, often with swashbuckling CEOs at the helm, (were) turning to new bosses who sport well-polished veneers of boringness."

U.S. law professor Ed Rock has characterized today's public company chief executives as "embattled" and has suggested "the central problem of U.S. corporate law for

\footnotetext{
$157 \quad$ Pub L 107-204, 116 Stat 745.

158 Alan Murray, 'After the Revolt' Wall St. J. (New York, 5 May 2007) A1.

159 Max Colchester, 'Today’s Bank Chiefs Can Spin a Yawn’ Wall St. J., (New York, 12 August 2013) C1.
} 
the last eighty years -- the separation of ownership and control -- has largely been solved."160 A new series of Enron-style scandals could quickly discredit this rather optimistic characterization of governance in the U.S. public company. Regardless, the foregoing account of the history of corporate governance in the U.S. indicates that broad trends affecting American public companies ensured that interest in corporate governance would not merely be sustained after the 1970s but would grow markedly. We will see next that similar trends were present in the U.K. by the beginning of the 1990s, meaning that corporate governance likely was destined to achieve prominence in Britain even without the work done by the Cadbury Committee.

Why Corporate Governance "Fit" Well in Britain in the 1990s

With corporate governance becoming a global phenomenon as the 1990s drew to a close, ${ }^{161}$ it was unlikely to by-pass the U.K. under any circumstances. Britain, however, was not a mere follower with corporate governance. Instead, the topic came to the forefront in the U.K. before it did in other countries, the U.S. excepted. ${ }^{162}$ The Cadbury Committee played a significant role in this process but there was more going on. The chronology of corporate governance's rise in Britain bears out the point. In 1990, the year before the Cadbury Committee was established and Britain was afflicted with its "unprecedented year for scandal", ${ }^{163}$ press coverage of corporate governance had started in earnest, academic analysis

$160 \quad$ Marcel Kahan and Edward Rock, 'Embattled CEOs' (2010) 88 Tex. L. Rev. 989, 989; Edward B. Rock, 'Adapting to the New Shareholder-Centric Reality' (2013) 161 U. Pa. L. Rev. 1907, 1909.

161 Text to $\mathrm{n} 217$.

162 Oxford Analytica Limited, Board Directors and Corporate Governance: Trends in the G7 Countries Over the Next Ten Years - Executive Report (Oxford Analytica Limited, 1992), 13, 19 (identifying the U.K. and the U.S. as well as Canada as the countries were corporate governance had achieved the highest prominence).

163 Text to $\mathrm{n} 131$. 
had begun and predictions were being offered that corporate governance would be a key 1990s theme. ${ }^{164}$

Why was corporate governance moving up the agenda in Britain and perhaps destined for prominence even before the corporate scandals that captured headlines and before the establishment of the Cadbury Committee? The recession Britain was experiencing no doubt played a role ${ }^{165}$ but the U.S. experience is also instructive. Trends that served to sustain interest in corporate governance there through the 1980s and prompted a move up the agenda in the early 1990s were replicated to a significant degree in Britain. Correspondingly, it is likely that as the 1990s began even in the absence of Cadbury ensuring proper accountability of executives was destined to become a higher priority. Corporate governance in turn would have been poised to become a significant feature of debates concerning British public companies.

\section{Takeovers}

One trend relevant to the growing prominence of corporate governance where there were parallels between the U.S. and the U.K. concerned takeovers. In Britain, as in the United States, when the hostile takeover activity that was a hallmark of the 1980s ceased attention turned increasingly to internal corporate governance mechanisms as a means of keeping managers in check. ${ }^{166}$ The Economist, in a 1994 survey of corporate governance, provided data showing that since 1990 the flow of hostile bids had dried up in both the U.S. and the U.K. and observed "In both countries, the demise of the hostile takeover has removed a vital source of contestability from the system of corporate governance." 167 As the

\footnotetext{
164 Text to nn 95-97.

165 Text to $\mathrm{n} 125$.

166 On the U.S. see text following n 149.

167 'Watching the Boss' Economist (London, 29 January 1994), 7, 13.
} 
Economist argued, the marginalization of takeovers as a governance device created in Britain a potential managerial accountability gap other mechanisms, such as board-level monitoring and shareholder activism, potentially could and should address. ${ }^{168}$ The fact that M\&A activity rebounded in the U.K. in the mid-1990s did not change matters. The deals of this era were strategic rather than financial in nature, with bidders seeking to acquire competitors to build market share and exploit economies of scale rather than to create value 1980s style by displacing underperforming managers. ${ }^{169}$

\section{Changes to the managerial function}

In the United States the "imperial" CEO of the 1990s replaced the "organization man" of the 1950s and 1960s. ${ }^{170}$ An increased emphasis on corporate governance was a logical counter-reaction to the trend, with the otherwise high-flying top executives of the 1990s being held at least partly in check by a combination of more robust (but still incomplete) oversight by boards and shareholders. Strong parallels can be found in Britain.

The 1950s and 1960s were something of a "golden age" for British business due to buoyant trading conditions and macroeconomic stability fostered by implementation of an agenda to manage world trade and finance set down at the Bretton Woods conference in 1944. ${ }^{171}$ In this benign economic environment increased bureaucratization, career ladders and "fitting in" by way of a strong commitment to corporate goals became hallmarks of

168 ibid., 13-17. See also Hamish McRae, 'The Changing Mood of Shareholders' Independent (London, 3 December 1991) 23.

169 William Kay, 'Takeover Fever is Back', Independent on Sunday (London, 29 January 1995), Business, 3; Nicholas Denton, 'Less of an Art and More of an Industry', Financial Times (London, 4 May 1995), International Corporate Finance survey, i.

170 Text to $\mathrm{n} 156$.

171 Sue Bowden, 'Corporate Governance in a Political Climate: The Impact of Public Policy Regimes on Corporate Governance in the United Kingdom" in Parkinson, Gamble and Kelly (n 61), 175, 177; Alan Dignam and Michael Galanis, The Globalization of Corporate Governance (Ashgate, 2009) 97, 222. 
management at larger British business enterprises. ${ }^{172}$ The Guardian claimed in 1965 that "The era of the rumbustious, larger than life entrepreneur is over." ${ }^{\prime 13}$ A couple of years later a former chief executive of a major food processing company said similarly "The tendency of big companies is to produce conformity and the organisation man." ${ }^{\prime 17}$ One by-product was that, as was the case in the 1950s and 1960s in the U.S., ${ }^{175}$ top executives of leading British companies executed their duties faithfully, or least faithfully enough to avoid major scandals. While the abrupt 1964 collapse of Rolls Razor, a washing machine retailer, prompted amendments to the London Stock Exchange listing rules governing disclosure, ${ }^{176}$ no incident occurring during the 1950s and 1960s was sufficiently serious to merit inclusion in a 2000 Financial Times survey of U.K. financial scandals of the $20^{\text {th }}$ century. ${ }^{177}$

A couple of decades later the situation was much different. Amidst an "abrupt" purge of managers U.K. companies executed in the 1980s "the promise of corporate loyalty began to look an absurd indulgence which preserved incompetents and preserved bureaucracies."178 While this created a harsh new reality for many executives, for others the free-wheeling 1980s provided a welcome boost as entrepreneurial capabilities became increasingly highly

172 Anthony Sampson, Company Man: The Rise and Fall of Corporate Life (Harper Colllins, 1995), 106-11; John F. Wilson and Andrew Thompson, The Making of Modern Management: British Management in Historical Perspective (OUP, 2006), 154.

173 William Davis, 'If Henry Ford Came Back Today' Guardian (London, 20 December 1965) 10. See also Geoffrey Wansell, Tycoon: The Life of James Goldsmith (Grafton Books, 1987), 232 (entrepreneurship extinct in the mid-1970s).

$174 \quad$ 'The Trend Towards Conformity' Guardian (London, 22 February 1967) 11 (quoting Avison Wormald, who had been CEO of Associated Fisheries).

175 Text to $\mathrm{n} 13$.

176 Cheffins (n 6) 357-58.

177 Richard Lambert, 'Charlatans: Financial Scandals of the $20^{\text {th }}$ Century' Financial Times (London, 1 January 2000), Thieves of the City, 12.

178 Sampson (n 172) 254, 307. 
valued. Takeover raiders such as Lord Hanson and Owen Green "were depicted by the media as national heroes, liberating companies from their overmanned bureaucracies."179

In Britain, as was the case in the U.S., an upgrading of corporate governance constituted a logical counter-reaction to the demise of "organization man", with or without Cadbury. As Anthony Sampson, a well-known "anatomist of Britain", ${ }^{180}$ observed in his 1995 book Company Man: The Rise and Fall of Corporate Life, "Faced with over-powerful bosses, the major investors in Britain and America became more seriously worried about what they discreetly called "corporate governance.",181 As early as 1990 U.K. institutional shareholders were said to be seeking "to limit the more autocratic type of manager." 182 A Guardian columnist said in a 1993 article on the "new culture" in boardrooms "The buccaneering entrepreneur is no longer so fashionable." 183 The Financial Times described the result:

"There has been a backlash against the excesses of the 1980s. Where swashbucklers once roamed, audit committees and remuneration committees now have their orderly procedures and have to be mollified." 184

The Sunday Times offered in 1993 a concise chronology of the transition: "If the 1970s was the decade of the establishment corporatists... and the 1980s were the decade of the self-made

\footnotetext{
179 ibid., 179 as well text to nn 48-50.

180 See Anthony Sampson, The Anatomy of Britain (Hodder and Stoughton, 1961), subsequently revised four times.
}

$181 \quad$ Sampson (n 172) 317.

182 'Sawing the Chair in Two' Financial Times (London, 17 December 1990) 22. See also Margaret Park, 'Institutions Fight One-Man Empires' Sunday Times (London, 9 December 1990), Business, 2.

183 Alex Brummer, 'New Culture at Large in the Boardroom' Guardian (London, 26 February 1993) 15. See also Lisa Buckingham, 'Swashbucklers Put to the Sword', Guardian (London, 12 December 1992) 38 ("some wayward instincts need to be guided and restrained").

184 'Animal Spirits’, Financial Times (London, 4 August 1995) 17. 
autocrats, the 1990s is emerging as a decade of low-key but highly professional technocrats." 185

Hanson itself proved the point. In 1991 it responded to criticism of its corporate governance - the term was in regular usage by then - by expanding its tiny contingent of non-executive directors. ${ }^{186}$ In 1993 Hanson abandoned plans to amend its articles of association to curtail shareholder rights amidst speculation that the company's business model had been compromised because the "raw, unbridled approach of the $80 \mathrm{~s} \mathrm{ha(d)} \mathrm{lost} \mathrm{its}$ respectability." 187 Lord Hanson's retirement in 1996, which coincided with the break-up of the Hanson conglomerate into four parts, was described as "the end of a chapter in the evolution of management.",188

\section{"Parallel changes...to (the) corporate lifestyle"}

It was not merely a coincidence that both Britain and the United States experienced a shift from "organization man" to corporate "buccaneers" to which the growing prominence of corporate governance was a logical response. As two guest columnists argued in the Times when commenting on the issuance of the May 1992 draft of the Cadbury report, "discussion underlying this is similar to that being held in America. Both countries have seen parallel changes and challenges to their corporate lifestyle." "Various examples of "parallel

185 Matthew Lynn and Rufus Olins, 'The Gold-Collar Workers' Sunday Times (London, 22 August 1993), Business, 3.

186 Alex Brummer, 'Hanson to Strengthen its Board' Guardian (London, 28 June 1991) 11; Ronald Rudd, 'Shareholders Surprised by Hanson Board Appointments' Financial Times (London, 19 September 1991), 21.

187 Ben Laurence, 'Hanson Bows to Investors' Campaign' Guardian (London, 18 June 1993), 15; “"New Man” Hanson’ Guardian (London, 26 June 1993) 34.

188 'Breaking Up the Broker' Financial Times (London, 26 September 1996) 15; see also Ross Tieman, 'Lord Hanson Prepares to Take His Leave' Financial Times (London, 26 September 1996) 17.

189 Vanni Treves and James Ukropina, 'Power Push From the Ranks' Times (London, 2 June 1992) 27. 
changes" can be identified that meant corporate governance likely was destined to rise to prominence in the early 1990s as a counter-reaction to changing managerial circumstances in U.K. public companies, regardless of Cadbury.

Deregulation, which in the U.S. increased the importance of the managerial function in firms ${ }^{190}$ was one "parallel change". With Britain joining the EEC in 1973, those running businesses in the 1980s had to adhere to numerous new EEC-inspired rules. ${ }^{191}$ Simultaneously, though, various deregulatory initiatives reshaped the British corporate landscape. ${ }^{192}$ Margaret Thatcher's Conservative government quickly eliminated exchange controls after coming to power in 1979 and subsequently reduced industry subsidies, privatized a wide range of nationalized industries, abolished restrictive practices in the financial services sector ("Big Bang") and took a relaxed stance towards foreign companies acquiring what had been regarded as implicitly untouchable "flagship" companies. ${ }^{193}$

A sharp decline in the bargaining power of unions was another trend that bolstered the latitude U.S. executives had as the $20^{\text {th }}$ century drew to a close. ${ }^{194}$ Again, there were strong British parallels. In the decades immediately following World War II, British unions were very powerful and employers eager to maintain labour peace did little to contest unionimposed restrictive practices, which in turn "had a significant effect on the authority,

\footnotetext{
$190 \quad$ Text following $\mathrm{n} 152$.

191 Jonathan Charkham, Keeping Good Company: A Study of Corporate Governance in Five Countries (Oxford University Press, 1994), 325.

192 Ivan Fallon, 'Viewpoint on a Decade of Corporate Upheaval' (London, 25 September 1994) Business, 6.

193 Geoffrey Owen, From Empire to Europe: The Decline and Revival of British Industry Since the Second World War (Harper Collins, 1999), 456-57.

194 Text following n 152.
} 
legitimacy and confidence of management."195 In contrast, in the 1980s, with the Conservative government having enacted legislation that restricted the ability of trade unions and their members to take industrial action and with union membership falling dramatically in the private sector, management "asserted their new-found authority" and "initiated offensives against union working practices."196

One other "parallel change" relating to the managerial function that set the scene for an increased emphasis on corporate governance in Britain was improved access to capital. In the U.S. this trend simultaneously expanded the opportunity set of executives while posing challenges by bolstering the firepower of potential rivals. ${ }^{197}$ Yet again the same sort of pattern emerged in Britain. For instance, Hamish McRae and Frances Cairncross, who published a book on "the City" in 1971 that they revised and updated on a number of occasions, said in the 1991 edition that while in 1971 the most severe criticism of the City was that it served British clients poorly, "That is no longer the case. The 1980s have seen radical advances in the variety and qualify of financial services available...to British businesses." 198 The available data confirm the point, with U.K. industrial and commercial

195 Wilson and Thompson (n 172) 207-8. See also Owen (n 193) 424, 433-35, 441-42; John Lloyd, 'A New Pattern Which Should Not Come Unstitched' Financial Times (London, 7 August 1985) 12.

196 Wilson and Thompson (n 172) 210-11. See also Owen (n 193) 425, 442-45; Ian Hamilton Fazey, 'Managerial Hawks in Search of Union Prey' Financial Times (London, 5 January 1981) 7; Philip Bassett, 'Labour's Winter of Discontent' Financial Times (London, 6 April 1987) 14; David Felton and Michael Harrison, 'Management on the Offensive' Independent (London, 12 May 1988) 15.

197 Text following $\mathrm{n} 152$.

198 Hamish McRae and Frances Cairncross, Capital City: London as a Financial Centre (Methuen, 1991), 252. 
companies relying in the late 1980 s on external sources of finance to an unprecedented degree to sustain an investment binge (Fig 4). ${ }^{199}$

Figure 4: UK Industrial and Commercial Companies - Sources of Finance, 1979-90

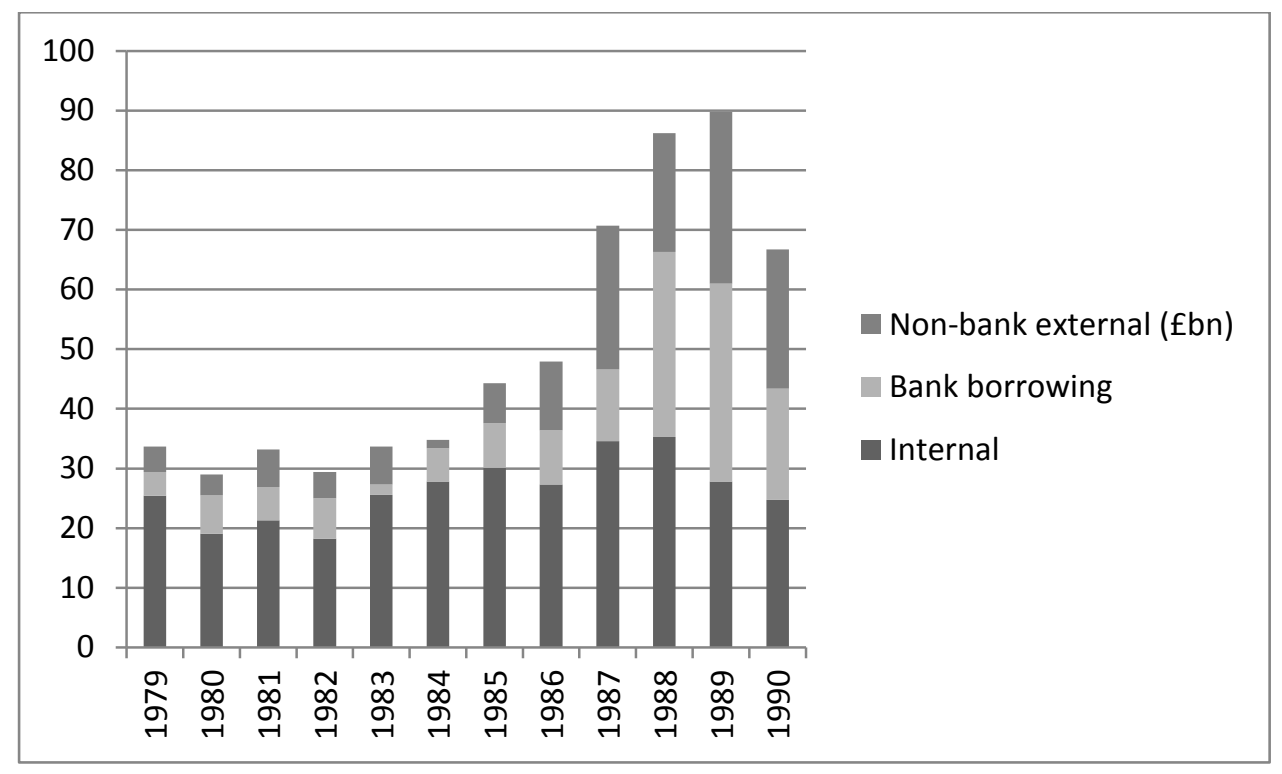

Source: Data derived from Charkham (1994) (n 191), 297.

The Maxwell scandal illustrated starkly how improved access to capital could have governance implications. While Maxwell had a chequered business history, securing finance was not a problem for him in the years immediately prior to the collapse of his business empire, in large measure because in the wake of the mid-1980s deregulation of U.K. financial markets bankers eager to stay competitive under more challenging conditions felt compelled

199 On the "investment binge", which tailed off during the recession of the early 1990s before recovering, see 'The Wheels of Investment Start to Turn' Economist (London, 22 April 1995) 29. There had been some liberalization of access to credit prior to the late 1980s. See Fabbio Braggion and Steven Ongena, 'A Century of Firm-Bank Relationships', (2014), working paper, available at http://www.fas.nus.edu.sg/ecs/events/seminar/seminarpapers/24Apr14.pdf (accessed 17 April 2015), 6 (indicating that with larger companies the proportion having borrowing relationships with only one bank as opposed to multiple banks fell substantially between 1970 and 1986). Nevertheless, as Figure 4 shows, there was a dramatic expansion of both bank borrowing and "external finance" in the late 1980s. 
to cut corners or take bigger financial risks. ${ }^{200}$ When the end came for Maxwell companies in his poorly governed business empire owed approximately $£ 1.5$ billion to banks. ${ }^{201}$

\section{Enhanced checks and balances}

Given the trends coinciding with the work of the Cadbury Committee that logically would have fostered concerns about managerial accountability and given various signs that corporate governance was moving higher on the agenda even prior to the launch of Cadbury $^{202}$, it seems likely that corporate governance would have risen to prominence in the U.K. in the early 1990s even if Cadbury had never happened. Regardless, however, of the exact chain of causation, governance not only was talked about more frequently in this era (Fig. 1, Fig. 2) but the monitoring of executives intensified. Though "(a) certain very British reserve... unmistakably remain(ed)"203 institutional shareholders became in the early 1990s considerably more willing to take corrective steps publicly in relation to the companies in which they owned shares. ${ }^{204}$ This new stance in turn enhanced the leverage of non-executive directors, which they proved willing to deploy on various occasions to orchestrate the

200 John Plender, 'The Elusive White Collar Criminal' Financial Times (London, 22 January 1996) 17.

201 Robert Peston, 'Little Room for City Excuses Over Maxwell' Financial Times (London, 9 January 1992) 17.

202 Text to nn $95-98,164$.

203 'Challenging Chaps’ Financial Times (London, November 10, 1997) 20.

204 Cheffins (n 41) 64; Tony Jackson, 'The Institutions Get Militant' Financial Times (London, 11 June 1991) 18; Fiona Walsh, 'Sweeping Out the Boardrooms' Sunday Times (London, 16 June 1991) Business, 9. 
dismissal of chief executives of prominent public companies. ${ }^{205}$ Pressure also built on companies in the early 1990s to link pay with performance, albeit with limited effect. ${ }^{206}$

The new checks imposed on Britain's senior executives under the mantle of corporate governance affected the culture of the publicly traded company. In 1995 the Economist described Britain's "new breed of bosses" as "workaholic administrators" who owed their elevation to pragmatism rather than vision. ${ }^{207}$ A Guardian columnist observed similarly "Cadbury it seems has helped to litter our boardrooms with technocrats, rather than swashbuckling entrepreneurs."208 There indeed were concerns expressed that 1990s Britain lacked "business heroes" and that beneficial "animal spirits" were "in short supply". ${ }^{209}$ The Hampel Committee, in its 1998 report, seemed sympathetic to this line of thinking, saying an “emphasis on accountability ha(d) tended to obscure a board's first responsibility - to enhance the prosperity of the business over time."210

While during the early 1990s time may have been called on "buccaneers" with "little time for the finer points of modern corporate governance"211 checks imposed on executives were certainly not robust enough to eliminate concerns about managerial accountability.

205 Cheffins (n 41) 106; John Plender, 'Tougher at the Top' Financial Times (London, 28 September 1991) Weekend, 7; David Clutterbuck and Dez Dearlove, 'Resigning is the "Acid Test” for Non-Execs' Sunday Times (London, 3 October 1993) Business, 2.

206 Simon Holberton, 'Time for Directors to Think Long-Term' Financial Times (London, 10 July 1991) 15; Lisa Buckingham, 'Greed Still the Boardroom Creed' Guardian (London, 2 May 1992) 38.

207 'Britain's New Bosses' Economist (London, 2 September 1995) 96. See also Lynn and Olins (n 185); Charles Leadbeater, 'Old Guard Moves Over' Financial Times (London, 4 January 1992) 7.

208 Alex Brummer, 'Britain Needs Perking Up With Some Tycoonery' Guardian (London, 15 April 1995) 34.

209 'Animal Spirits' (n 184).

210 Committee on Corporate Governance (n 117) 7.

211 Martin Dickson, 'The Buccaneers Who No More Go a'Roving' Financial Times (London, 20 July 2002) 13. 
Executives during the 1990s continued to have in various ways discretion their 1950s and 1960s counterparts would envy and the "superstar" CEO syndrome that had become prevalent in the U.S. took root at least to some degree in Britain, with expectations and remuneration to match. ${ }^{212}$ Correspondingly, even in the absence of British versions of Enron and WorldCom, amidst ongoing debates concerning board structure and operation, newsworthy instances of shareholder activism and recurrent executive pay controversies corporate governance would remain a high-profile issue in the U.K. ${ }^{213}$ More scrupulous oversight of executives may indeed help to explain why Hanson and BTR-style M\&A activity never returned - "the City...got a lot better at ousting incompetent management with far less drama and cost.",214

Corporate governance did not entirely extinguish potentially counterproductive "animal spirits" in British business. The imprudent behaviour of various leading banks prior to the 2008 financial crisis illustrated the point. ${ }^{215}$ Nevertheless, changes to the managerial function did help to ensure that corporate governance would become in the early 1990s an integral feature of the public company landscape and would remain so thereafter. The

212 Michael Brett, 'When the Going Rate Keeps Going Up' Independent (London, 28 July 1991) 12 (saying that under a "star" system of remuneration already well developed in the U.S., CEO pay was increasing relative to other executives); Don Young and Pat Scott, Having Their Cake...How the City and Big Bosses are Consuming UK Business (Kogan Page, 2005) 12, 111, 171; Gideon Haigh, Fat Cats: The Strange Cult of the CEO (Thunder's Mouth Press, 2005), 8-9, 60.

213 See Cheffins (n 6) 385-86 (shareholder activism); Derek Higgs, Review of the Role and Effectiveness of Non-Executive Directors (Stationery Office, 2003) (non-executive directors); Jane Simms, 'Has the Milk Gone Sour for Fat Cats?' Accountancy, September 2002; 'Fat Cats Feeding', Economist (London, 11 October 2003) 83; Adrian Michaels, 'Off the Leash: What Will Bring Executive Pay Under Control?' Financial Times (London, 24 August 2004) 11 (executive pay).

214 Matthew Lynn, 'Three Reasons to Celebrate the Death of the Megadeal' Telegraph, March 10, 2015, Business, 2.

215 Walker Review (n 4) 24-27, 33; Owen, (n 64) 53-54;. 
outcome likely would have been the same even in the absence of the deliberations of the Cadbury Committee.

Conclusion

British deliberations concerning corporate governance had a substantial impact globally, due in large measure to receptivity to the path-breaking work the Cadbury Committee did in the early 1990s. ${ }^{216}$ Given the U.K.'s outsized Cadbury-sparked influence, it might be thought that Britain was the place where the concept of corporate governance first achieved notoriety and that corporate governance was unlikely to have come to prominence in the U.K. absent Cadbury. As this paper has indicated, on both counts the situation was quite different. Corporate governance emerged from linguistic obscurity in the U.S. nearly two decades before this occurred in Britain, with a preoccupation with industrial democracy in the 1970s and a robust market for corporate control in the 1980s helping to keep corporate governance off the agenda in the U.K. until the beginning of the 1990s. Corporate governance in turn likely was destined to rise to prominence in Britain at that point in time Cadbury or no Cadbury -- due to the demise of 1980s-style hostile takeovers and due to managerial discretion being enhanced by deregulation, the decline of trade unions and liberalized access to capital.

The underlying trends which meant that corporate governance would have become a priority in Britain regardless of Cadbury had strong parallels in the U.S. What about the rest of the world? By 1998, to quote a report by an OECD corporate governance advisory group, corporate governance was a topic "of great international interest and concern." 217 Did the

\footnotetext{
216 Text to nn 118-22.

217 Business Sector Advisory Group on Corporate Governance, Corporate Governance: Improving Competitiveness and Access to Capital in Global Markets (OECD, 1998) 7.
} 
same trends that accounted for corporate governance's rise to prominence in the U.S. and the U.K. explain the rise of corporate governance globally? This is highly unlikely.

As the 1998 OECD report acknowledged, corporate governance arrangements differ across borders depending on various factors. ${ }^{218}$ Ownership patterns are particularly crucial. Whereas in Britain and the U.S. managerial accountability is the top priority because a separation of ownership and control is the norm in publicly traded companies, ${ }^{219}$ elsewhere dominant shareholders prevail and addressing the potential costs - primarily potential exploitation of outside investors -- associated with this type of ownership structure logically will be top of the governance agenda. ${ }^{220}$ Given that this paper has focused on managerial accountability rather than minority shareholders and has sought to explain the rise of corporate governance in the U.S. and the U.K. at least partly by reference to an expansion of the opportunity set of executives, the analysis provided here is unlikely to have substantial explanatory power with respect to other countries. It is beyond the scope of this paper to explain why corporate governance ultimately flourished worldwide. An important consideration, however, was that companies in a wide range of countries were seeking capital to compete in an increasingly global marketplace and needed to be responsive to concerns investors - often U.S.-based - had about proceeding without suitable checks and balances being in place. ${ }^{221}$

While the trends that meant that the rise of corporate governance likely was inevitable in Britain in the 1990s even without Cadbury were not international in orientation, the

\section{8 ibid, 9.}

219 Text to nn 5, 29.

220 Text to n 29; Ronald J. Gilson, "Controlling Shareholders and Corporate Governance: Complicating the Comparative Taxonomy" (2006) 119 Harvard L Rev 1641, 1643, 1649-52. 221 Cheffins (n 2) 58; Paul Davies et al., 'Boards in Law and Practice: A Cross-Country Analysis in Europe' in Paul Davies et al. (eds), Corporate Boards in Law and Practice: A Comparative Analysis in Europe (Oxford University Press, 2013), 3, 95. 
Cadbury Committee's work did ensure that corporate governance deliberations in the U.K. had cross-border ramifications. Though Britain's ownership and control arrangements differ from those in most other countries, an American academic observed in 1998 that "the process by which British businesses have addressed the problems of governance have a singularly appealing character." ${ }^{222}$ Cadbury, with the promulgation of its novel code of best practice and its innovative "comply or explain" enforcement scheme, deserves much of the credit. As a distinguished German corporate governance expert has acknowledged, "Since the Cadbury Report in 1992, the corporate governance code movement has swept from the U.K. all over the world." ${ }^{, 23}$ Hence, even if corporate governance was destined to come to the U.K. in the absence of Cadbury, the impact which deliberations in Britain had globally can be attributed primarily to the distinctive brand of corporate governance reform the Cadbury Committee pioneered rather than substantially similar corporate governance trends or arrangements.

222 J.W. Barnard, 'The Hampel Committee: A Transatlantic Critique' (1998) 19 Co Lawyer 110, 111.

223 Hopt (n 42) 97 (emphasis in original). 